\title{
13. ORGANIC GEOCHEMISTRY OF LOWER CRETACEOUS SEDIMENTS FROM SITE 535, LEG 77, FLORIDA STRAITS ${ }^{1}$
}

\author{
J. P. Herbin, G. Deroo, and J. Roucaché, Institut Français du Pétrole, Direction de Recherche, \\ Géologie et Géochimie, 92506 Rueil Malmaison Cedex, France
}

\begin{abstract}
At Site 535, the four lithologic units of Cretaceous age are controlled by two types of sedimentologic facies: (1) the massive light-colored limestones or marly limestones in which the total organic carbon (TOC) content is low and the organic matter more or less oxidized and (2) laminated dark facies in which the TOC content is higher and associated with a well-preserved organic matter of Type II origin. Very little typical Type III organic matter occurs in the whole series from late Berriasian to Aptian and Cenomanian. Fluctuations from oxidizing to reducing environments of deposition are proposed to account for the variations in properties of the Type II organic matter between the different facies. Dark laminated layers are good but immature potential source rocks: petroleum potential is often higher than $2 \mathrm{~kg} \mathrm{HC} / \mathrm{t}$ of rock.
\end{abstract}

\section{INTRODUCTION}

Site 535, drilled during Leg 77 and located in the Straits of Florida at a water depth of $3455 \mathrm{~m}$ (Fig. 1), allows the study of the Lower Cretaceous formations in the eastern Gulf of Mexico. Five lithologic units were described on board (Fig. 2) with few postcruise modifications in their age. Because the sediments are mainly calcareous, with generally more than $50 \%$ and sometimes up to $99 \% \mathrm{CaCO}_{3}$, the lithologic basis for the division of Cretaceous into Units II, III, IV, and V are relatively subtle. The main characteristics of the lithology consist of rhythmic alternations of carbonates: light bioturbated limestones, dark and more or less laminated limestones, and dark marly limestones, which were interpreted on board as "... fluctuations of the anaerobic bottom conditions coupled with plankton productivity..." (see site chapter, Site 535, this volume).

During the Berriasian to Cenomanian, the Blake-Bahama and the Hatteras formations were deposited in the North Atlantic Ocean. Many similarities exist between the alternations of the Blake Bahama Formation as they were defined at Sites 105 and 391 and those of the Units III, IV, and V at Site 535. The lithologic change between a calcareous set and a noncalcareous one, which in central North Atlantic makes the difference between the Blake-Bahama and the Hatteras formations, doesn't exist at Site 535. This dissimilarity could be partly due to a relatively shallow paleobathymetry above the calcite compensation depth (CCD) at Site 535 (presently Site 535 is $3455 \mathrm{~m}$ deep) compared to the depths at which the Blake-Bahama and the other formations were deposited: Sites 105, 367, and 391 (where the present bathymetry is approximately $4500-5000 \mathrm{~m}$ ).

The geological "El Event" (de Graciansky et al., 1982), which in the central North Atlantic corresponds to the change from Blake-Bahama Formation to Hat-

\footnotetext{
${ }^{1}$ Buffler, R. T., Schlager, W., et al., Init. Repts. DSDP, 77: Washington (U.S. Govt. Printing Office).
}

teras Formation, is not indicated at Site 535 by a variation of lithofacies. However, near the top of Unit III, a great condensation (perhaps a hiatus) occurs. Only four of eight Aptian foraminiferal zones were recovered, including two of late Aptian and two of early Aptian age, but none from the middle Aptian; most if not all of the Barremian is missing (see Site 535 report, this volume).

\section{SAMPLING AND METHODS}

More than 120 samples were collected, 71 of them representative of the Cretaceous lithofacies in Cores 18 to 75 and 55 others in a detailed sequence along a single core (Sections 535-64-3 to 535-64-5).

Organic carbon was determined in acid-treated samples with a LECO apparatus, after which Rock-Eval pyrolysis assays were performed for all 126 samples (Espitalié et al., 1977).

Espitalié and others (1980) showed that the mineral matrix of rocks, especially clays, induced retention of hydrocarbons during pyrolysis. Accordingly, the hydrogen index (HI) of a rock is lower than the HI obtained for the demineralized fraction (kerogen) of the same rock. In order to estimate the petroleum potential of organic matter, we must know the quantity of hydrocarbons held on the mineral matrix during the pyrolysis of the studied rock. The activity of the mineral matrix is determined from mixing the carbonate-free sample (previously pyrolyzed under $\mathrm{O}_{2}$ ) and the standard rock. The comparison between the quantity of hydrocarbons released during a Rock-Eval pyrolysis from this mixture with those of the standard rock alone allows determination of the activity of the mineral matrix of the studied rock (Espitalié et al., in press). Thus we obtain the "corrected hydrogen index" $\left(\mathrm{HI}^{\prime}\right)$, which is more representative of the organic matter than the uncorrected index (HI). Such a correction was carried out for samples from Site 535 whenever there was ambiguity about the type of organic matter.

Elemental analysis of the kerogen was done for 12 samples, and 20 samples were extracted with chloro- 


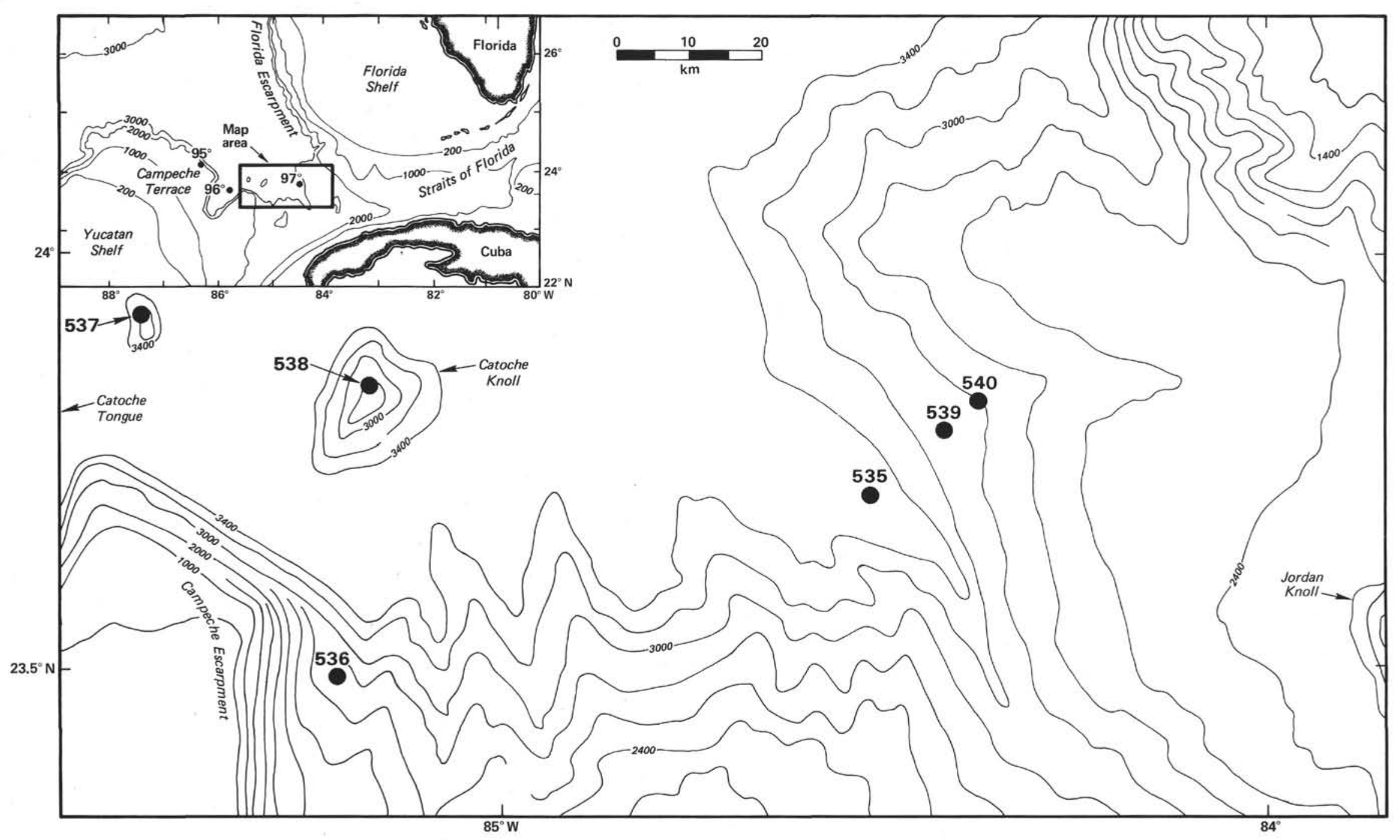

Figure 1. Location of Site 535. 
Site 535

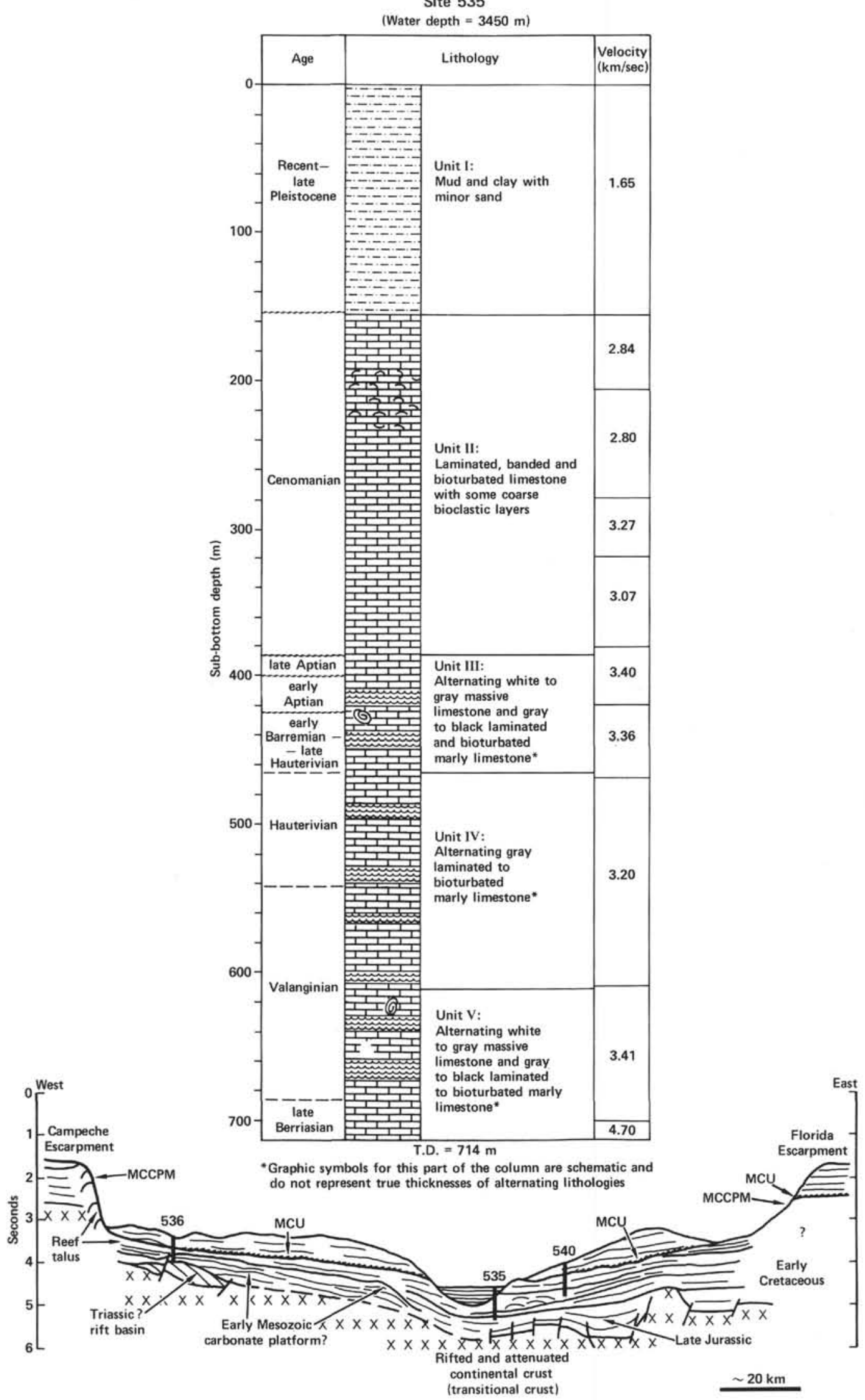

Figure 2. Schematic log and section of Site 535 (water depth $=3455.5 \mathrm{~m}$ ). MCU = mid-Cretaceous unconformity; MCCPM = mid-Cretaceous carbonate platform margin. 
form. A quantitative estimate of saturate, aromatic, and heteroatomic compounds was made with a IATROSCAN analyzer. With this device, the different components are fractionated by thin-layer chromatography on silicagelcoated rods and then passed through a flame-ionization detector in order to measure their abundances. Ten micrograms of total extracts are required for this destructive method.

\section{RESULTS}

In order to give a wider statistical geochemical characterization of the Cretaceous sequence under study, and because of the accuracy of the Rock-Eval data whatever the apparatus, the 43 Cretaceous samples analyzed on board by L. B. Magoon and J. W. Patton will be discussed again in this study (see site chapter, Site 535, this volume).

\section{Analysis of Carbon and Organic Matter}

We will first discuss carbon and pyrolysis data for a detailed sequence in Unit IV and then for every lithologic unit in geologic order. Because carbonate lithofacies along the whole series are diverse, each lithofacies is designated with a particular symbol (Table 1).

\section{Detailed Analysis of a Sequence in Unit IV (Fig. 3)}

An interval of $3.65 \mathrm{~m}$ was sampled in Core 64 to examine a representative lithologic sequence, from a massive light-colored limestone through finely laminated and progressively darker limestones to another massive lightcolored limestone. The lithologies will be discussed below in the order of the sedimentation (from bottom to top).

The white and light gray marly limestones at the base of the sequence $(535-64-5,76 \mathrm{~cm}$ to $535-64-4,128 \mathrm{~cm})$ are rich in carbonate contents $(87-94 \%)$ and have TOC values ranging from 0.0 to $0.5 \%$. Slight TOC enrichments $(0.8 \%)$ are observed in Sample 535-64-4, $141 \mathrm{~cm}$ and in a thin level of laminated gray marly limestones at

Table 1. Symbols for lithofacies.

\begin{tabular}{|c|c|c|c|}
\hline $\begin{array}{c}\mathrm{CaCO}_{3} \\
(\%)\end{array}$ & Lithofacies & Symbol & Color \\
\hline \multirow[t]{2}{*}{$95-100$} & Limestones & $\stackrel{\Delta}{4}$ & $\begin{array}{l}\text { White }(5 Y 8 / 1-5 Y 8 / 2) \\
\text { Pale yellow gray }(5 Y 8 / 4)\end{array}$ \\
\hline & Marly limestones & $\underset{\varnothing}{\varnothing}$ & $\begin{array}{l}\text { White }(5 Y 8 / 1-5 Y 8 / 2) \\
\text { Pale yellow gray }(5 Y 8 / 4) \\
\text { Light gray }(5 Y 7 / 1-5 Y 7 / 2) \\
\text { Dark gray }(5 Y 4 / 1)\end{array}$ \\
\hline \multirow[t]{2}{*}{$65-95$} & $\begin{array}{l}\text { Laminated marly } \\
\text { limestones }\end{array}$ & $\begin{array}{l}\theta \\
\frac{8}{2} \\
2 \\
2\end{array}$ & $\begin{array}{l}\text { White }(5 Y 8 / 1-5 Y 8 / 2) \\
\text { Pale yellow gray }(5 Y 8 / 4) \\
\text { Gray }(5 Y 5 / 1-5 \mathrm{Y} 6 / 1) \\
\text { Dark gray }(5 \mathrm{Y} 4 / 1) \\
\text { Dark olive gray }(5 \mathrm{Y} 3 / 2)\end{array}$ \\
\hline & Marls & X & $\begin{array}{l}\text { Dark gray }(5 Y 4 / 1) \\
\text { Very dark gray }(5 Y 3 / 1)\end{array}$ \\
\hline$<65$ & Laminated marls & 联 & $\begin{array}{l}\text { Dark gray }(5 \mathrm{Y} 4 / 1) \\
\text { Dark olive gray }(5 \mathrm{Y} 3 / 2)\end{array}$ \\
\hline
\end{tabular}

Sample $535-64-5,23 \mathrm{~cm}$. At the top of the light marly limestone gray set, a level of laminated gray marly limestones with $0.7 \%$ TOC represents the contact with the laminated dark gray marly limestones (535-64-4, 90-121 $\mathrm{cm})$. In the latter, the TOC increases abruptly, with a range of $1.8-3.6 \%$ as the carbonate decreases from 80 to $69 \%$. When the very dark gray marls are reached (535-64-4, 56-70 cm), the carbonate content falls to 56 and $44 \%$ and TOC values reach $5.7 \%$ (even $13.2 \%$ for a shipboard analysis). A negative correlation between the carbonate content and the TOC is clearly apparent (Fig. 4A) in this interval. An abrupt change is observed in the laminated gray marly limestones: from 535-64-4, $20-49 \mathrm{~cm}$, the carbonate contents reach $78-90 \%$ and the TOC values $0.6-0.9 \%$. At the top, however, 535-64-4, 1-16 cm, one slight TOC enrichment (1.2-1.7\%), related to a relatively poor carbonate content of $71-74 \%$ is observed. Above it, in laminated pale yellow gray marly limestones $(535-64-3,139-145 \mathrm{~cm})$, where the hues become lighter, the carbonate contents regularly increase $(75-84 \%)$ and the TOC decreases $(1.0-0.6 \%)$. That trend ends at Sample 535-64-3, $135 \mathrm{~cm}$, where a white marly limestone-characterized by the same high carbonate contents (84-90\%) and low TOC contents $(0.0-0.4 \%)$, as at bottom of this sequence-begins.

In summary, this examination shows for a complete sequence a progressive passage from massive, light-colored to laminated, darker deposits. This macroscopic change is accompanied by a decrease of carbonate contents and increase of TOC contents. The maximum TOC enrichment occurs at top of the darker facies, a decrease occurs for the overlying laminated deposits, whereas the white marly limestone at the top are nearly devoid of organic carbon. From bottom to top, abrupt changes in TOC content occur from the lower massive member to the laminated one $(535-64-4,122-128 \mathrm{~cm})$ and from dark to light-colored laminae between $535-64-4,56 \mathrm{~cm}$ and $535-64-4,49 \mathrm{~cm}$. On the other hand, a progressive change characterizes the passage from the laminated to the upper massive member at 535-64-3, 135-139 cm.

The nature of the organic matter (OM) deduced from the hydrogen index $(\mathrm{HI})$ versus oxygen index (OI) diagram of pyrolysis is as follows:

1) The base of the laminated member, 535-64-4, 95$121 \mathrm{~cm}$, is characterized by a typical Type II marine OM $\left(\mathrm{HI}=426\right.$ to $642, \mathrm{HI}^{\prime}=524$ to $\left.699, \mathrm{OI} \leq 65\right)$. These characteristics of pyrolysis were soon reached in the light gray marly limestones at Sample 535-64-4, $141 \mathrm{~cm}$ (HI $=591, \mathrm{HI}^{\prime}=763$, OI $=69$ ).

2) Higher concentrations of TOC corresponding to the same type of OM occurs in the overlying dark gray marls $\left(\mathrm{HI}=480\right.$ to $578, \mathrm{HI}^{\prime}=632$, OI $=25$ to 44$)$.

3) In the other laminated sediments, $535-64-4,49 \mathrm{~cm}$ to 535-64-3, $139 \mathrm{~cm}$ and at the bottom (Sample 535-64-4, $122 \mathrm{~cm}$ ), the $\mathrm{OM}$ is also of marine origin ( $\mathrm{HI}=313$ to $455, \mathrm{HI}^{\prime}=383$ to 681 ) but the higher OI (71 to 142 ) would imply a relative enrichment in oxygenated compounds.

4) In the massive, light-colored members, the relative enrichment of OI continues to increase (150 to 200) and 


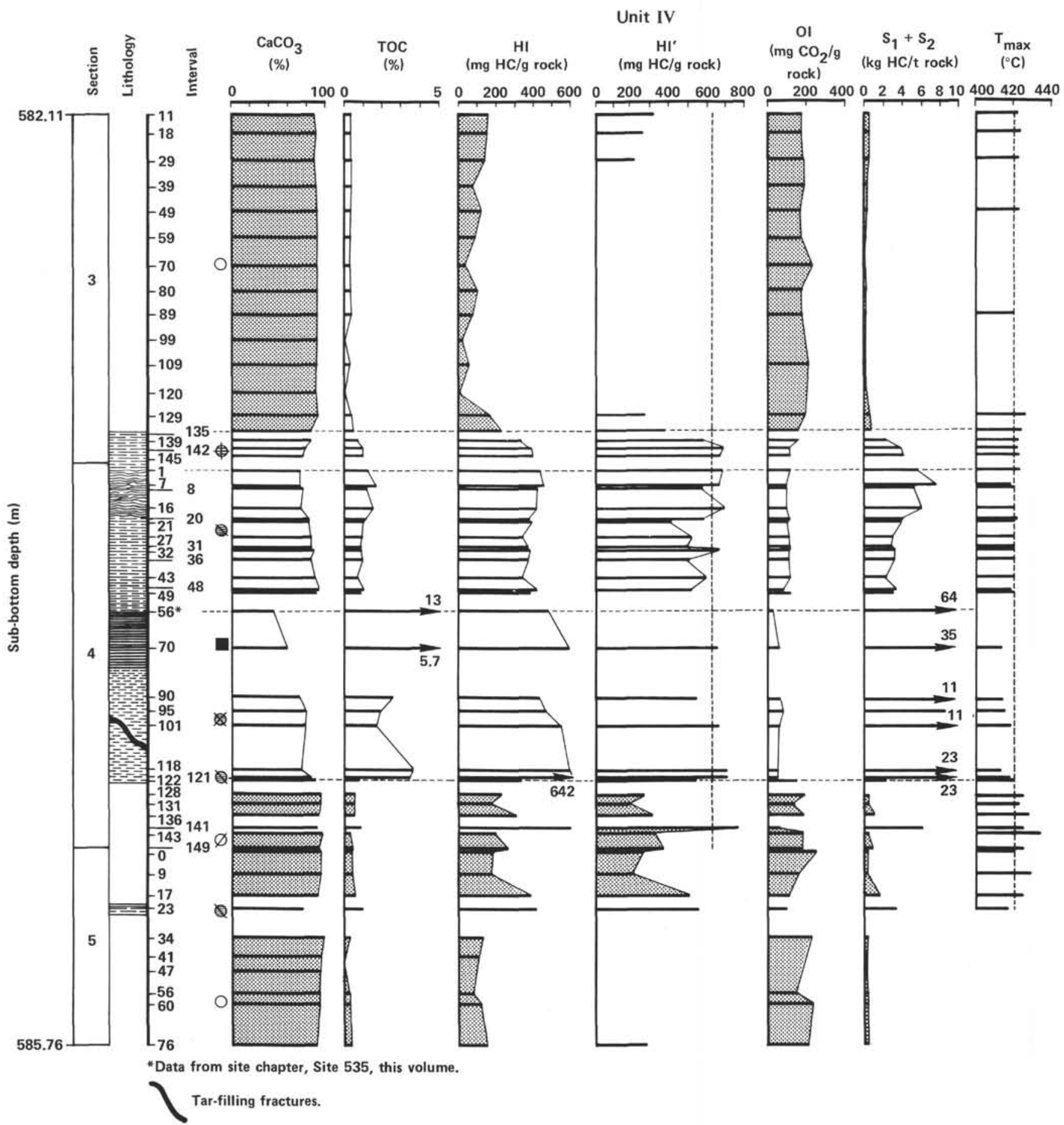

Figure 3. Vertical distribution of geochemical data in Sections 535-64-3 through 535-64-5. See Table 1 for key for symbols.

the related $\mathrm{HI}^{\prime}$ decreases ( 344 to 172 ), except for layers at $535-64-5,17 \mathrm{~cm}$ and $535-64-5,23 \mathrm{~cm}\left(\mathrm{HI}^{\prime}=489\right.$ to 548 ), which also belong to Type II marine OM.

5) The other samples located beneath evolution Path III (Fig. 4B) belong to white marly limestone with very poor TOC contents $(\leq 0.2 \%)$; their pyrolysis data are not reliable enough to indicate the nature of OM.

In order to complete the results obtained with the pyrolysis method, some kerogen elemental analyses were done on laminated sediments of Core 535-64. These results, discussed in the section on kerogen fractions, confirm the Type II origin of the OM contained in the laminated pale yellow gray, the laminated gray, and the laminated dark gray marly limestones that was indicated by the homogeneous values of the corrected hydrogen indices $\left(\mathrm{HI}^{\prime}\right)$ in the laminated part (Fig. 3).

According to sedimentologic analyses, the bioturbated light-colored carbonates are derived from well-oxygenated environments, whereas the laminated darker sediments are associated with oxygen depletion (lack of bio- 
Unit IV

(Sections 3-5 of Core 64)

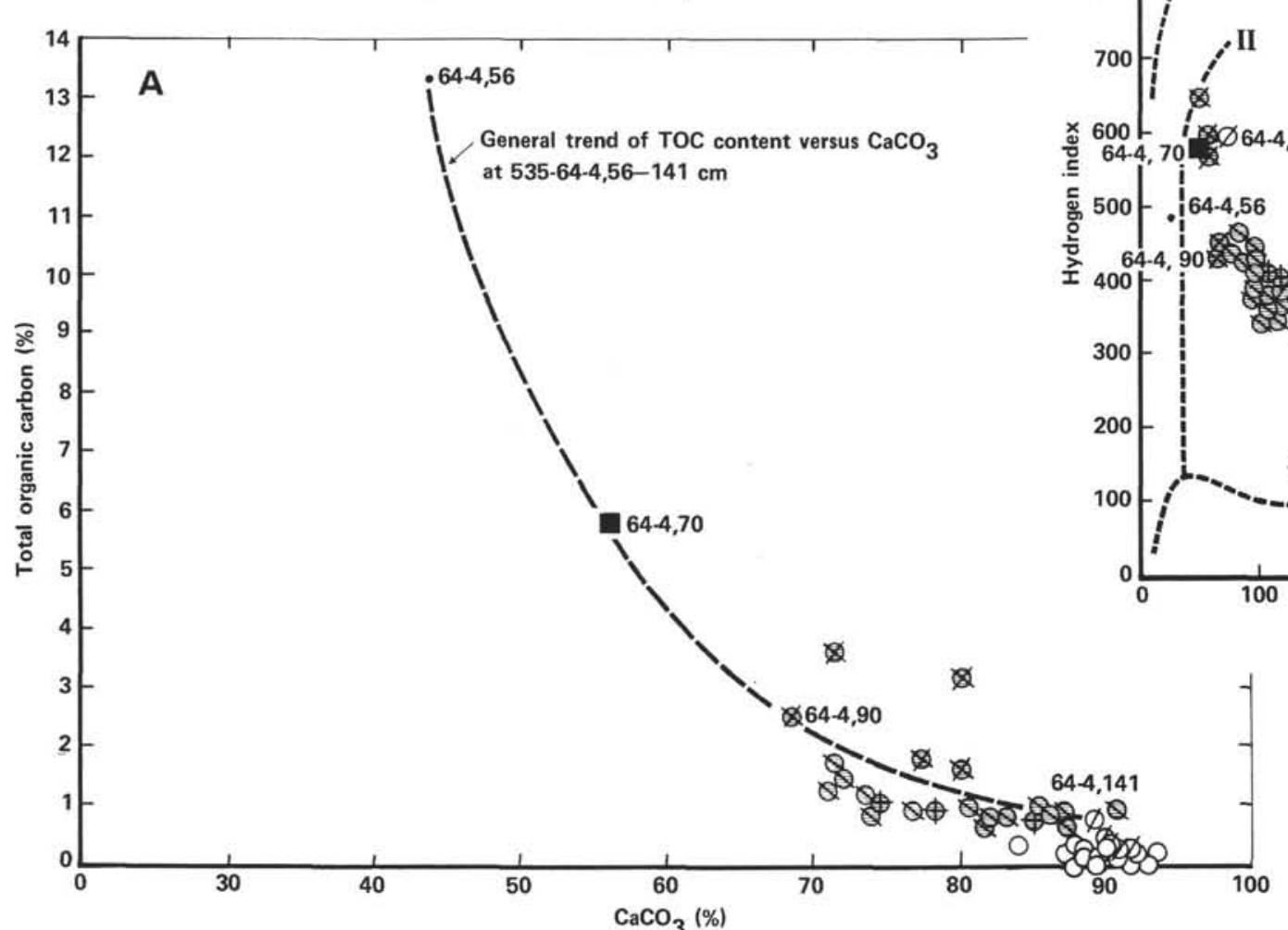

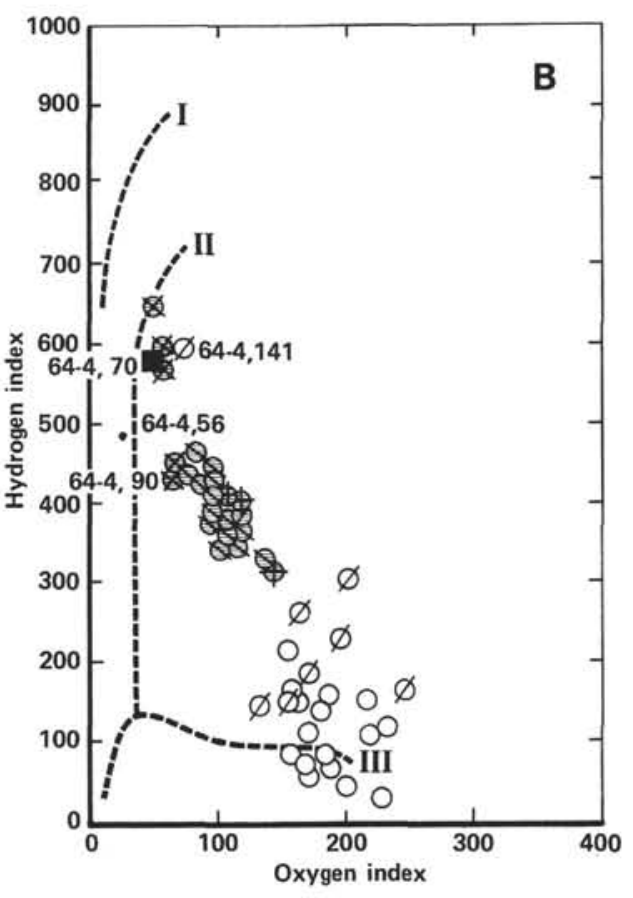

Figure 4. Carbonate versus total organic carbon content diagram (A) and pyrolysis diagram (B) for Sections 535-64-3 through 535-64-5. See Table 1 for key to symbols. Numbers represent core-section, level in $\mathrm{cm}$.

turbation). Such alternations between the two environments would explain the variations for both $\mathrm{HI}$ and $\mathrm{OI}$.

The phenomenon of OI increases simultaneous to the HI decreases suggests the alteration of the OM. Stch a phenomenon was observed along a core of Toarcian shales collected in a quarry of the Paris Basin; at the bottom of the core, a well-preserved OM reveals high $\mathrm{HI}$ and low OI, but progressively towards the surface, low HI and high OI correspond to the same but weathered and oxidized OM. Such a phenomenon could exist in a synsedimentary process between two environments with one more oxygenated than the other.

\section{Analysis of the Lithologic Units}

\section{Unit V: Core 535-79 to Section 535-68-5 (Fig. 5)}

The oldest unit cored at this site is of late Berriasian to Valanginian age. It consists of alternating massive, bioturbated to poorly laminated white limestones and marly limestones with few dark gray or dark olive gray marls, both laminated and unlaminated.

White limestones contain $96 \% \mathrm{CaCO}_{3}$ and $0.1-0.2 \%$ TOC and white marly limestones have 76-94\% $\mathrm{CaCO}_{3}$ and $0.1-0.3 \%$ TOC (Fig. 5A). Both contain organic mat- ter of undetermined origin; their unreliable pyrolysis data are located outside of Paths II and III (Fig. 5B).

Laminated white marly limestones, with $82-91 \%$ $\mathrm{CaCO}_{3}$, reach $0.4-0.6 \%$ TOC, whereas the laminated dark olive gray marly limestones (Sample 535-72-4, 87 $\mathrm{cm}$ ) contain only $74 \% \mathrm{CaCO}_{3}$ with $2.3 \%$ TOC. Both laminated lithofacies show organic matter of predominantly marine Type II ( $\mathrm{HI}=304$ to $339, \mathrm{HI}^{\prime}=385$ to 460) (Fig. 5B, Appendix).

Dark gray marls, laminated dark gray marls, and dark olive gray marls reveal lower carbonate contents (41$60 \%$ ) and higher TOC contents (1.6-2.8\%) (Fig. 5A). Higher values of $\mathrm{HI}$ are obtained in the laminated facies of dark gray marls (Sample 535-69-1, $115 \mathrm{~cm}$ ) or dark olive gray marls (Sample 535-71-3, $122 \mathrm{~cm}$ ) with $\mathrm{HI}=$ 425 to 439 , whereas in the unlaminated facies (Sample $535-73-1,93 \mathrm{~cm}$ ) HI doesn't exceed 306. However, the corrected hydrogen indexes reach 563 to 594 (Appendix), a value that is characteristic of marine Type II organic matter.

Samples of marls studied by Magoon and Patton (see site chapter, Site 535, this volume) have higher TOC values (up to $6.6 \%$ ) but reach the same range of HI (300 to 400) (Figs. 5A-B). They therefore contain the same type of OM. 


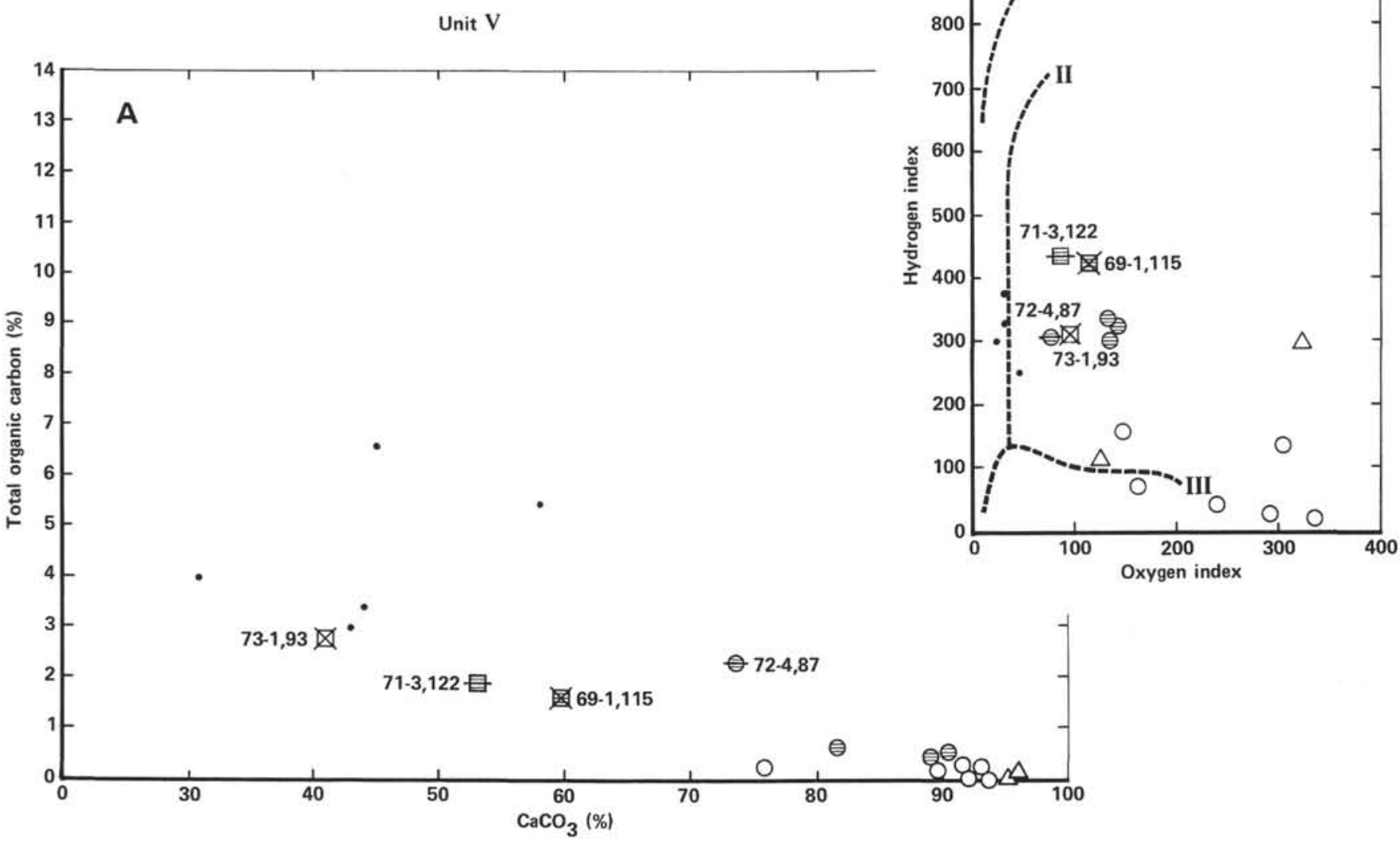

Figure 5. Carbonate versus total organic carbon content diagram (A) and pyrolysis diagram (B) for Unit V. See Table 1 for key to symbols. Numbers represent core-section, level in $\mathrm{cm}$. Solid dots are data from site chapter, Site 535, this volume.

\section{Unit IV: Sections 535-68-2 to 535-52-2 (Fig. 6)}

The detailed sequence studied above belongs to this unit, which is Valanginian in age at bottom and Hauterivian at top. It consists of numerous alternations of bioturbated and more or less laminated white, pale yellow gray, and light gray limestones or marly limestones with dark gray, dark olive gray, and black marls, both laminated and unlaminated.

The white limestone in Sample 535-63-4, $138 \mathrm{~cm}$ is very rich in carbonate $(99 \%)$ and almost devoid of organic carbon $(0.2 \%)$. White marly limestones with $84-$ $95 \% \mathrm{CaCO}_{3}$ and $0.0-0.4 \%$ TOC (Appendix, Figs. 4A and $6 \mathrm{~A}$ ) contain an indeterminate organic matter; the only reliable pyrolysis data for these are from Sample $535-58-5,37 \mathrm{~cm}$, where HI $=367$ for a TOC of $0.4 \% * 2$, which can be attributed to an OM of Type II origin. Pale yellow gray and light gray marly limestones show a carbonate content fluctuating between 89 and $92 \%$ with $0.2-0.8 \%$ TOC (Figs. 4A and 6A); most of these belong to the detailed sequence of Core 64 previously described with mostly indeterminate OM, except in the samples richer in TOC. The white, pale yellow gray, gray, dark

\footnotetext{
2 An asterisk ( $\left.{ }^{\bullet}\right)$ indicates that the analyses were made twice in order to verify the
} results. gray, and dark olive gray laminated marly limestones, like the dark gray marls, have lower carbonate contents (61-85\% with $0.5-3.6 \%$ TOC content) and contain an organic matter of marine origin with $\mathrm{HI}$ fluctuating between 276 (for the lower TOC content, $0.5 \%$ in Sample $535-66-5,129 \mathrm{~cm}$ ) and 642 (in Sample 535-64-4, $121 \mathrm{~cm}$, for a TOC content of 3.2\%) (Figs. 4B and 6B; Appendix).

\section{Unit III: Sections 535-52-2 to 535-43-3 (Fig. 7)}

The age assigned to this unit is late Hauterivian to earliest Albian; the late Barremian and Gargasian foraminiferal zones are absent. The hiatus during the Gargasian represents the El Event (de Graciansky et al., 1982), which in the central North Atlantic separates the carbonate Blake-Bahama Formation and the low-carbonate Hatteras Formation. Such a carbonate change is not observed at Site 535; Unit III consists entirely of cyclic alternations of unlaminated white limestones and marly limestones; laminated gray, dark gray, or dark olive gray marly limestones; and dark gray to very dark gray marls.

The white limestones are very rich in carbonate (9699\%) and sometimes rich in TOC (Samples 535-47-1, 82 $\mathrm{cm}$ and $535-47-1,99 \mathrm{~cm}$ reach respectively 0.5 and $0.8 \%$ TOC* with $99 \%$ carbonate; Fig. 7A, Appendix). Detrital components (silt, clay) are completely missing in this 


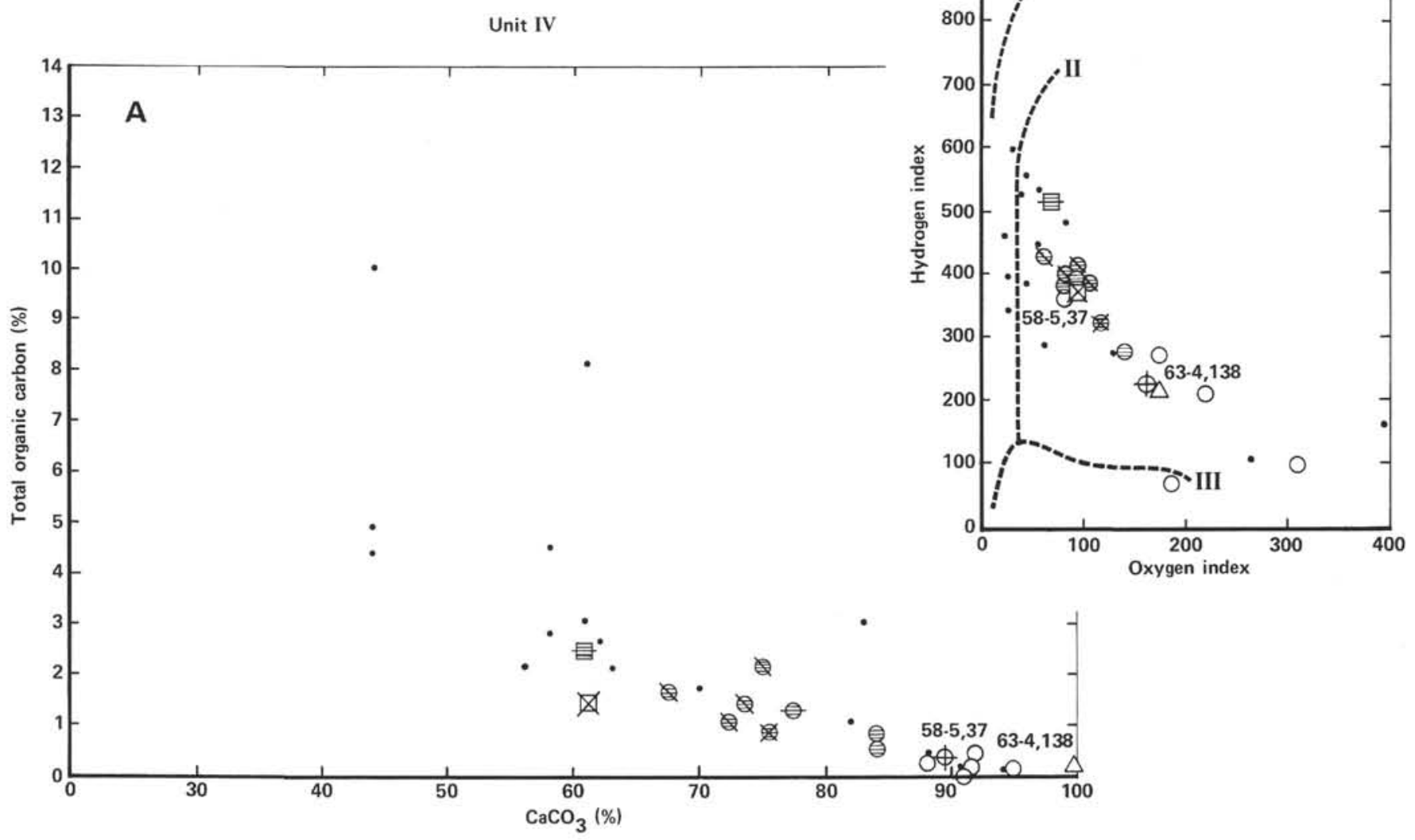

Figure 6. Carbonate versus total organic carbon content (A) and pyrolysis diagram (B) for Unit IV. See Table 1 for key to symbols. Numbers represent core-section, level in $\mathrm{cm}$. Solid dots are data from site chapter, Site 535, this volume.

facies, which consists only of $\mathrm{CaCO}_{3}$ and $\mathrm{OM}$. Sample $535-47-1,99 \mathrm{~cm}$ is particularly interesting, because, despite a high carbonate content, its $\mathrm{HI}$ is 423 , i.e., it derives from typical Type II OM (Fig. 7B).

The pale yellow gray limestone (Sample 535-47-1, $91 \mathrm{~cm})$ is also very rich in carbonate $(99 \%)$ as well as in organic matter $(0.6 \%$ TOC*) (Fig. 7A, Appendix) with a typical Type II OM (Fig. 7B).

White and pale yellow gray marly limestones, like the laminated white marly limestones $\left(89-95 \% \mathrm{CaCO}_{3}\right)$, have the same range of TOC as the above limestones (0.2$0.6 \%$, Fig. 7A, Appendix) and are located in the same pyrolysis field except for the laminated white marly limestones in Sample 535-49-3, $111 \mathrm{~cm}$, which have slightly higher TOC contents $(0.9 \%)$ and HI values (387, Fig. 7B). Laminated gray, dark gray or dark olive gray marly limestones contain $75-91 \% \mathrm{CaCO}_{3}$ and $0.7-1.8 \%$ TOC (Fig. 7A); these are all derived from Type II organic matter with $\mathrm{HI}$ values between 256 and $418\left(\mathrm{HI}^{\prime}\right.$ from 370 to 557 ).

Despite higher TOC contents (2.3-3.2\%, Fig. 7A), the less calcareous facies (dark gray or very dark gray marls) with $52-65 \% \mathrm{CaCO}_{3}$ show equivalent values of HI (260-403, Fig. 7B). Without the retention caused by clay material during pyrolysis, the range of $\mathrm{HI}^{\prime}$ lies between 391 and 590 (Appendix), so that a Type II origin can be assigned to the OM.

\section{Unit II: Section 535-43-2 to 535-17,CC (Fig. 8)}

Two subunits were considered in Unit II based upon the stronger cyclicity exhibited in the lower part (see site chapter, Site 515, this volume).

The lower subunit (Section 535-43-2 to Core 535-30) is Cenomanian(?) on the basis of ammonites (Young, this volume); the initial determination of an early to middle Albian age has been interpreted as reworking. In turn, the upper subunit (Core $535-30$ to $535-17, C$ ) is attributed to middle Cenomanian (largely on the basis of ammonites), and the benthic foraminifers of early to middle Albian age are considered as reworked.

Despite an important hiatus ( $8 \mathrm{Ma}$ ) corresponding to the entire Albian, no fundamental changes of lithology are observed between Units III and II. In Unit II, the series consists of the same lithofacies described before (i.e., cross-laminated alternations of white limestones or marly limestones with pale yellow gray, light gray, and dark gray marly limestones and a few dark olive gray marly limestones or laminated black marls).

The white limestone (Sample 535-35-4, $97 \mathrm{~cm}$ ) is very rich in carbonate and almost devoid of TOC $(0.2 \%)$. White and pale yellow gray marly limestones contain 91-94\% $\mathrm{CaCO}_{3}$ and are slightly richer in TOC $(0.2-$ $0.6 \%$ ). Light gray marly limestones are less rich in carbonate $(80-90 \%)$ with the same range of TOC $(0.3-0.5 \%$, 


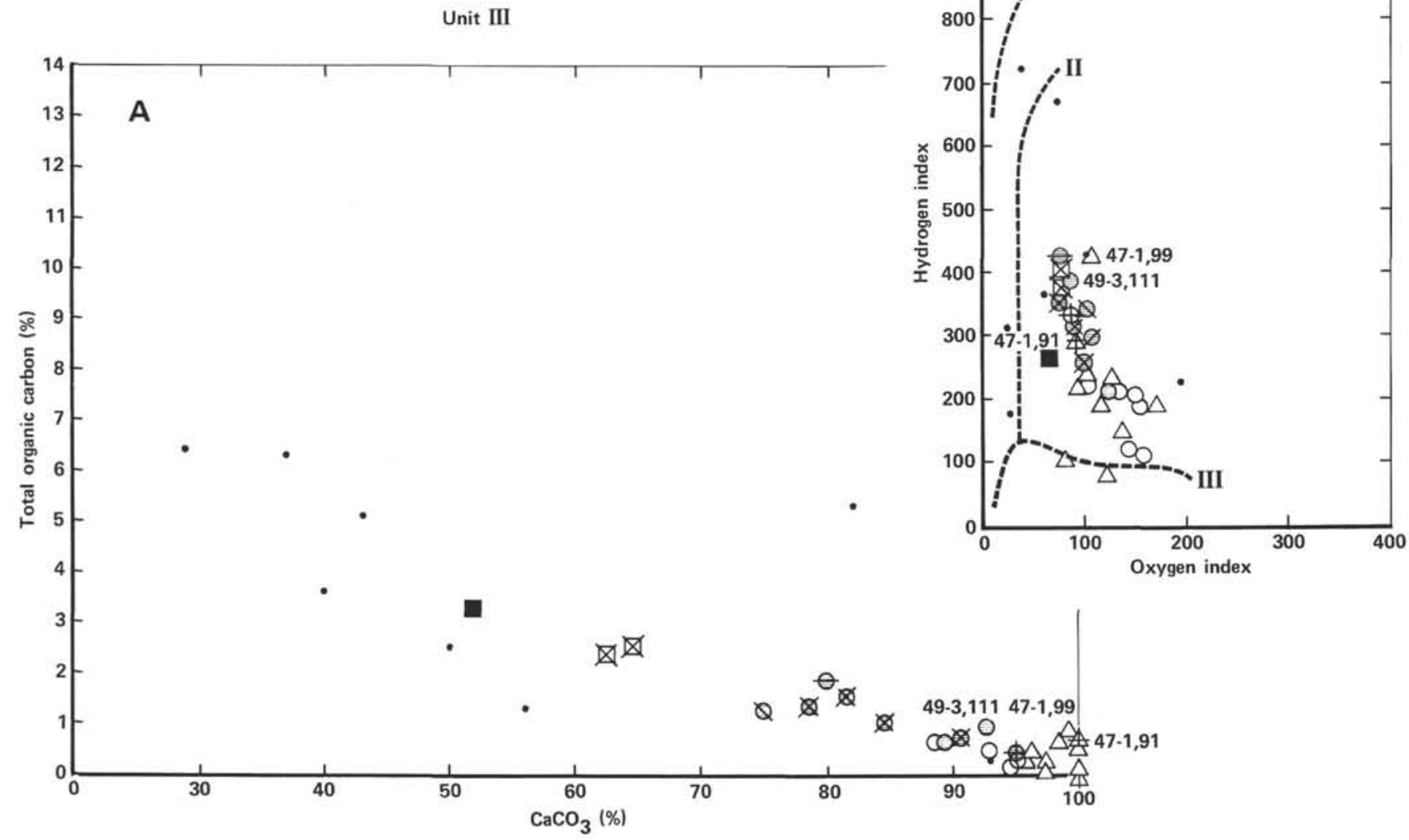

Figure 7. Carbonate versus total organic carbon content (A) and pyrolysis diagram (B) for Unit III. See Table 1 for key to symbols. Numbers represent core-section, level in $\mathrm{cm}$. Solid dots are data from site chapter, Site 535, this volume.

Fig. 8A). In the dark gray marly limestones (Sample $535-35-4,82 \mathrm{~cm}$ ), the carbonate content reaches $81 \%$ and TOC content $1.5 \%$. As observed in Unit IV, the light-colored, unlaminated facies contains an oxidized $\mathrm{OM}$ of marine origin ( $\mathrm{HI}^{\prime}$ up to 375 ), whereas the dark unlaminated lithofacies corresponds to an unoxidized Type II OM (HI' = 523) (Fig. 8B, Appendix). The laminated facies consist of dark olive gray marly limestones (Sample 535-35-4, $140 \mathrm{~cm}$ ) or dark gray marls (Sample $535-41-6,120 \mathrm{~cm})$ and have respectively 82 and $61 \%$ $\mathrm{CaCO}_{3}$ and 2.2 and $0.9 \%$ TOC. A typical marine $\mathrm{OM}$ is found for Sample 535-35-4, $140 \mathrm{~cm}$ and an altered one for the other. The richest TOC values were obtained on board in Samples 535-42-5, $21 \mathrm{~cm}$; 535-41-5, $121 \mathrm{~cm}$; and $535-35-5,15 \mathrm{~cm}$, with respectively $7.3,4.0$, and $5.4 \%$ TOC. Their HIs ranging between 330 and 510 (Fig. 8B) are typical of a Type II organic matter. Thus, although the lithofacies with dark hues are less represented in Unit II, the type of organic matter always belongs to Type II, more or less oxidized, with no evidence for a detrital influence of Type III organic matter.

\section{Comparison of Organic Matter and Carbonate Sedimentation in Sites $\mathbf{3 6 9}$ and $\mathbf{5 3 5}$}

The proximity of the platform in both places (the continental slope off the Spanish Sahara for Site 369 and the eastern Gulf of Mexico carbonate platform for Site 535) accounts for the lithologic analogies. Carbonate-rich sediments occur within the Albian series in Hole 369A (Core 369A-47 to Section 369A-41-2), just as they occur in the mid-Cretaceous of Site 535.

In Hole 369A, the lithofacies of the Albian section consists of alternations of gray, dark gray, and very dark gray marly limestones and marls. Silty gray marls contain $22-55 \% \mathrm{CaCO}_{3}$ and $1.2-8.8 \%$ TOC. Very dark gray marls or marly claystones have $12-42 \% \mathrm{CaCO}_{3}$ and $1.0-8.5 \%$ TOC, whereas marly limestones are richer in carbonate $(78-87 \%)$ and poorer in TOC $(0.5-0.8 \%)$. All the lithofacies contain the same Type II OM with HI reaching up to 550. The absence of any typical detrital $\mathrm{OM}$ of continental origin (Type III) and a decrease of the HI versus increase of the OI related to a decrease of the TOC content are observed as they were at Site 535 (Fig. 9). In both cases, the OM is predominantly of marine origin. The dilution of the TOC and the low HI observed for the more calcareous sediments could depend on fluctuations of the sediment accumulation rate connected with redox states of the sedimentary environment.

At roughly the same period, the two sites had the same organic sedimentology induced by identical geologic environments and by a strong influence of the carbonated sedimentation. 


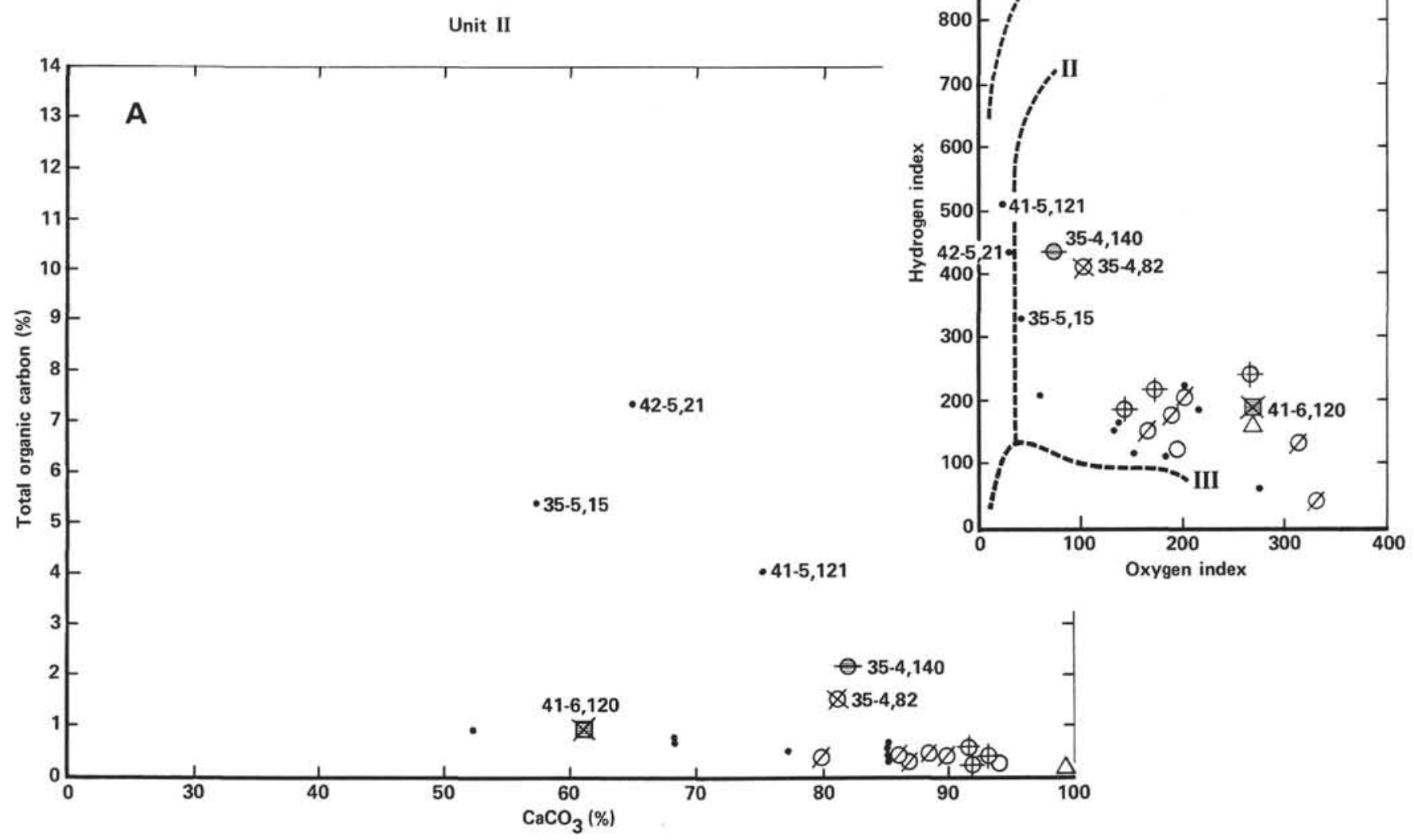

Figure 8. Carbonate versus total organic carbon content (A) and pyrolysis diagram (B) for Unit II. See Table 1 for key to symbols. Numbers represent core-section, level in $\mathrm{cm}$. Solid dots are data from site chapter, Site 535, this volume.

\section{Petroleum Potential and Maturation of the Organic Matter}

Petroleum Potential (Fig. 10)

The petroleum potential is defined as the sum of Rock-Eval Peak $\mathrm{S}_{1}$ (corresponding to the free hydrocarbons $[\mathrm{HC}]$ in the rock) and Peak $\mathrm{S}_{2}$ (related to the $\mathrm{HC}$ expelled during the kerogen pyrolysis). Five ranges of petroleum potential will be considered here under: (1) very low potential, $0.01-0.50 \mathrm{~kg} \mathrm{HC} /$ metric ton of rock $(\mathrm{kg} / \mathrm{t})$; (2) low potential, 0.51-2.00; (3) medium potential, 2.01-5.00; (4) good potential, 5.01-20.00; (5) very good potential, above 20.00 .

Because the OM throughout the whole study is of marine origin (Type II), a correlation of the petroleum potential with the TOC content can be made. The organic carbon content is related to lithology, so the petroleum potential will follow the same correlation.

Figure 10 shows that very low potentials are restricted to white limestones or marly limestones and light gray marly limestones.

Low potentials are characteristic of unlaminated lithologies including limestones or marly limestones with pale hues such as white, pale yellow gray, or light gray. However some laminated white marly limestones (535$71-1,110 \mathrm{~cm} ; 535-69-4,120 \mathrm{~cm} ; 535-66-5,129 \mathrm{~cm}$; and
535-48-1, $100 \mathrm{~cm}$ ) also have low potentials (between 1.3 and $2.0 \mathrm{~kg} \mathrm{HC} / \mathrm{t}$ rock), like some laminated dark gray marly limestones (535-48-1, $78 \mathrm{~cm}$ ) and marls (535-41-6, $120 \mathrm{~cm}$ ).

Medium potentials are frequent in the white, pale yellow gray, gray, or dark gray laminated marly limestones. One white limestone reaches $3.68 \mathrm{~kg} \mathrm{HC} / \mathrm{t}$ with $0.8 \%$ $\mathrm{TOC}^{3}$ in 535-47-1, $99 \mathrm{~cm}$ (its carbonate content is $99 \%$ ).

Good and very good potentials are characteristic of laminated marly limestones or marls with dark hues such as gray, dark gray, very dark gray, and dark olive gray.

The petroleum potential of the sediments at Site 535 depends on the frequency and thickness of dark laminated layers.

\section{Stage of Maturation (Fig. 11)}

The hydrogen index can be correlated with the maximum temperature of S2 pyrolysis peak during programmed heating from 350 to $550^{\circ} \mathrm{C}$. Numerous reference samples at different stages of maturation and for different types of organic matter were analyzed by pyrolysis and for vitrinite reflectance (Durand et al., 1979;

\footnotetext{
${ }^{3}$ The analyses were made twice (once after chloroform extraction) in order to eliminate possible contamination.
} 


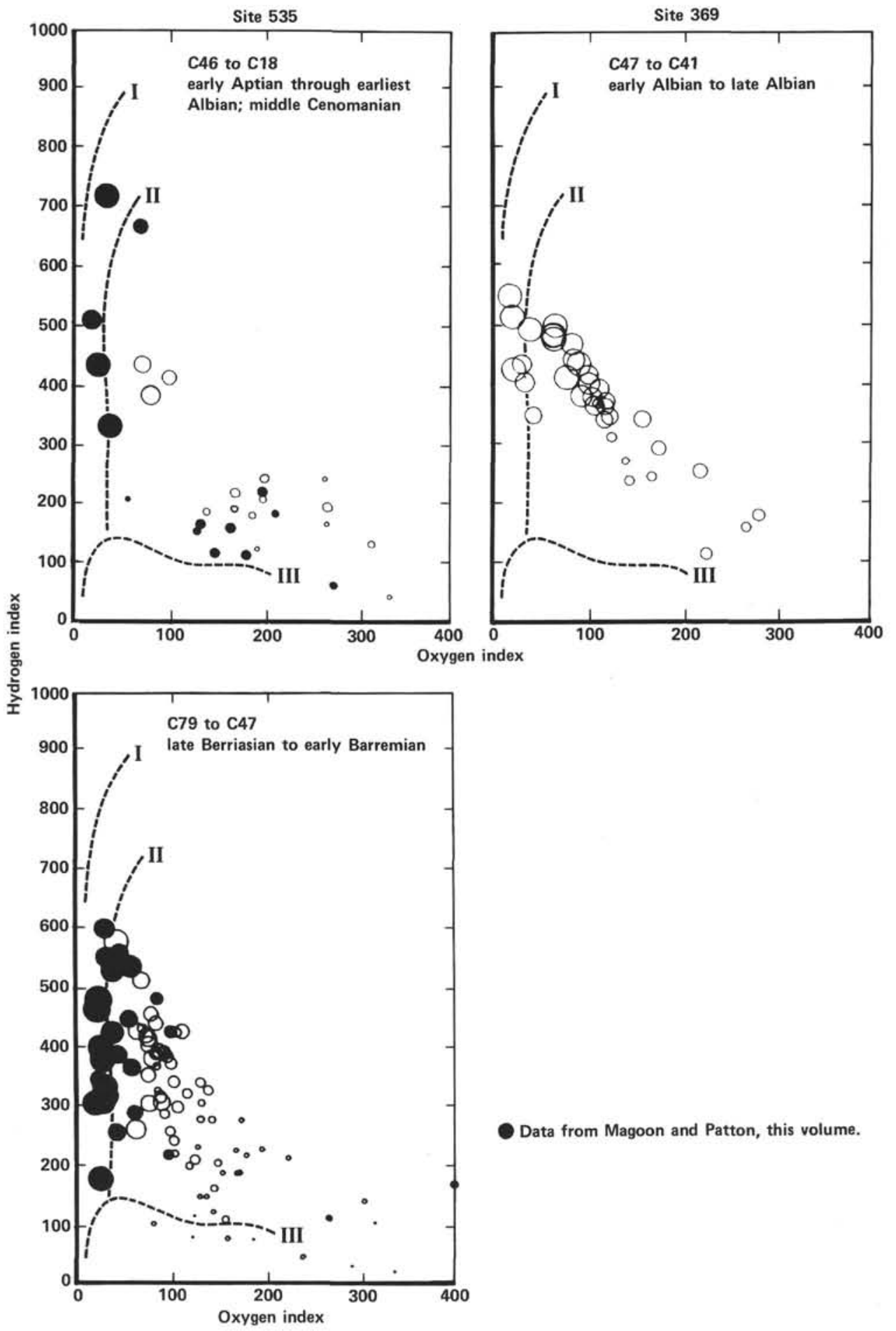

Figure 9. Comparison of the pyrolysis diagrams from Sites 369 and 535. Both sites are located on the continental margin with a relatively low bathymetry, above the CCD. Size of symbols is proportional to TOC.

Herbin et al., 1979). The results allowed the plotting of evolution paths of the different types of organic matter (I, II, III) with related isoreflectance curves superimposed (Espitalié, in press). Reflectances below $0.5 \%$ belong to immature material; the oil window is located beyond $0.5 \%$ (approximately $435^{\circ} \mathrm{C}$ ) up to $1.0 \%$ (approximately $450^{\circ} \mathrm{C}$ ).
All samples from Site 535 (Fig. 11) are located in the immature zone $\left(<0.5 \% R_{0}\right.$, where $R_{0}=$ vitrinite reflectance) with a fluctuation of the $T_{\max }$ between 408 and $434^{\circ} \mathrm{C}$. No maturation of the organic matter is observed in the successive units; the same range of $T_{\max }$ exists from Unit V to Unit II (i.e., for an interval from 700$150 \mathrm{~m}$ depth). The present depth of $150 \mathrm{~m}$ for Unit II is 

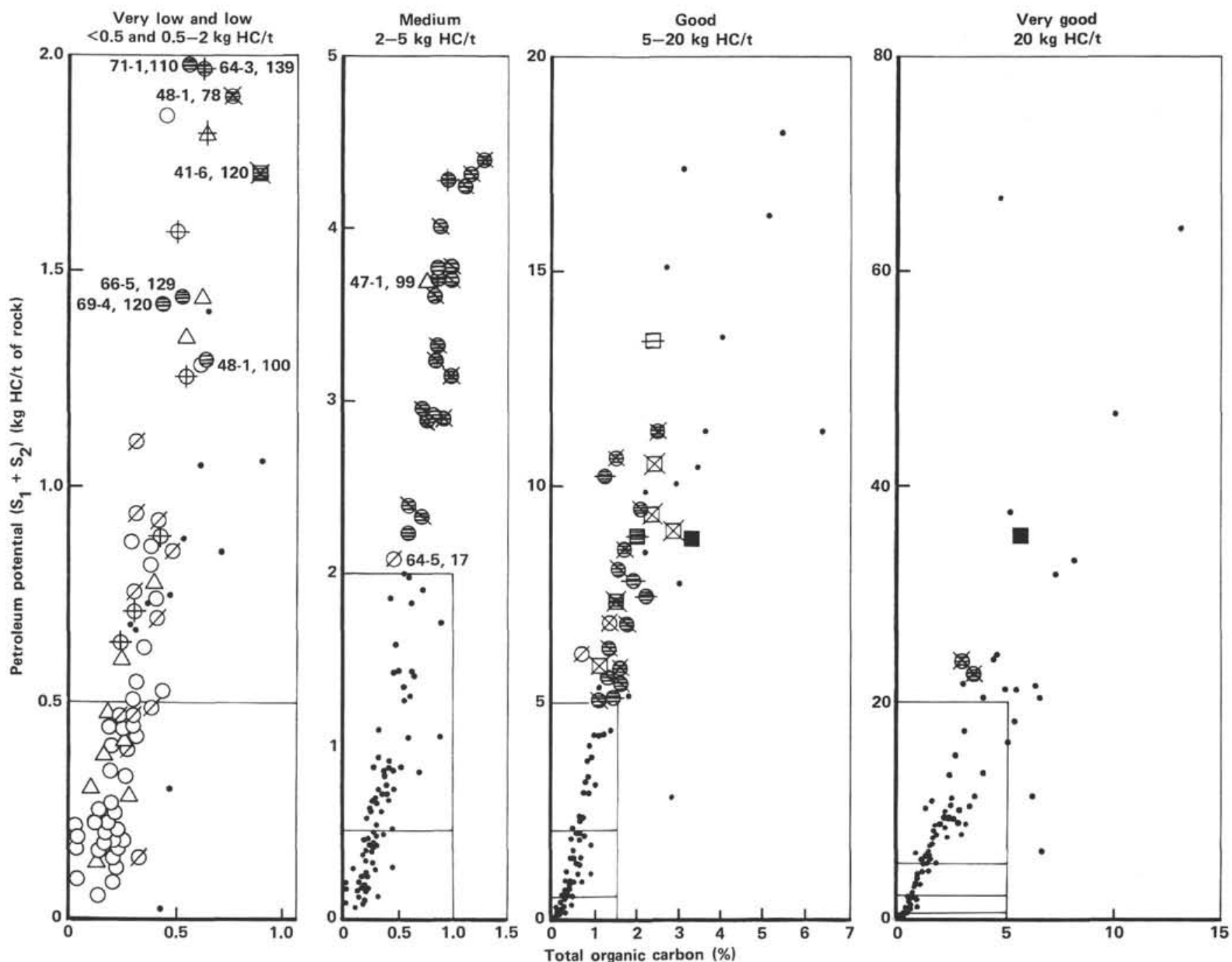

Figure 10. Petroleum potentials at Site 535. See Table 1 for key to symbols. Solid dots are data from Site 535 report (this volume).

not sufficient to explain the average $\mathrm{T}_{\max }$ of $425^{\circ} \mathrm{C}$. A comparison of the evolution of $\mathrm{T}_{\max }$ versus depth with a more complete Cretaceous section as found in Site 540 would permit the estimation of the thickness of the eroded deposits before the Pleistocene sedimentation.

\section{Study of the Kerogen Fractions (Fig. 12)}

Elemental analysis of kerogen was performed on 12 samples; seven were located in the detailed sequence of the Sections 535-64-3 through 535-64-5 (Table 2). The samples were chosen in different lithologies: laminated pale yellow gray, gray, dark gray, and dark olive gray marly limestones and laminated dark gray marls, with $61-82 \%$ carbonate, $0.8-3.6 \%$ TOC and a wide range of pyrolysis indices (high HI/low OI or low HI/high OI). Unfortunately, the study of light-colored unlaminated limestones and marly limestones was not undertaken, because of the low TOC content.

The results of the elemental analysis of the kerogen do not show a scattering of the values as observed on pyrolysis result. The whole population of the studied samples is located beneath the beginning of the evolu- tion Path II except for the Sample 535-64-4, $118 \mathrm{~cm}$, which is above. Thus the marine origin of the organic matter is corroborated in the detailed sequence of Sections 535-64-3 and 535-64-4, from bottom to top of the laminated set and confirmed in the slightly laminated level at 535-64-5, $23 \mathrm{~cm}$.

\section{Study of Chloroform Extracts (Fig. 13)}

Because of their small size, the samples yielded very low quantities of extract (Table 3), less than $4 \mathrm{mg}$ on the average, ranging from $0.6 \mathrm{mg}(535-48-1,68 \mathrm{~cm})$ to 13.6 $\mathrm{mg}(535-47-1,93 \mathrm{~cm})$. The heteroatomic compounds account for 78.4-100\% of the extracts. The low content of hydrocarbons (HC) and the predominance of heteroatomic compounds are typical of immature material and are in agreement with the early stage of maturation (given by the pyrolysis temperature). The saturated and unsaturated $\mathrm{HC}$ content ranges from $0-13.9 \mathrm{wt} . \%$, and the aromatic fractions represent $0-7.7 \mathrm{wt} . \%$ of the extract. The saturated and unsaturated $\mathrm{HC}$ are so weakly represented that study by gas chromatography was attempted on only two samples: Sample $535-35-4,140 \mathrm{~cm}$ 


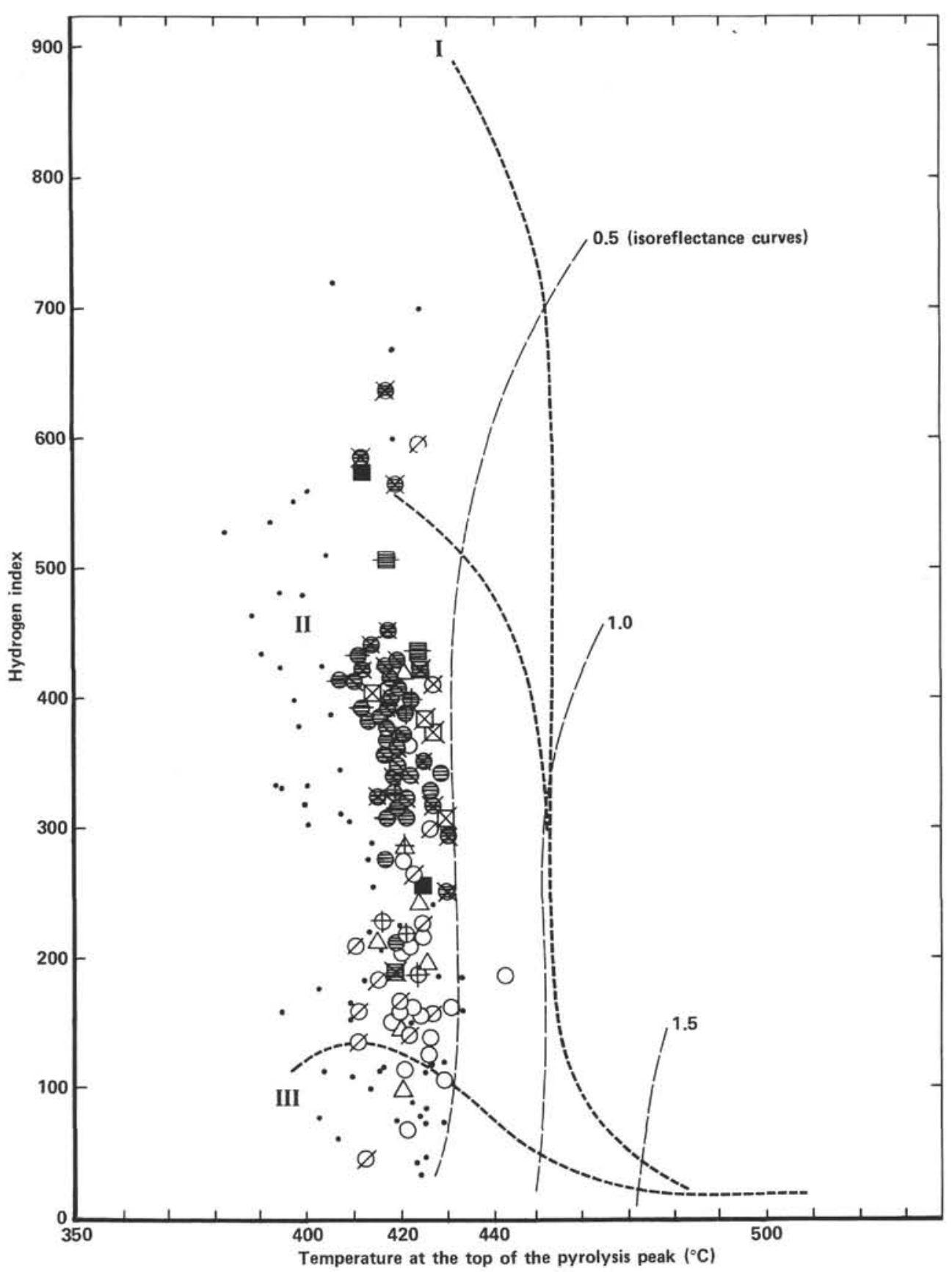

Figure 11. Stage of maturation of the organic matter at Site 535. See Table 1 for key to symbols. Solid dots are data from site chapter, Site 535 , this volume.

(TOC $=2.24 \%)$, where $8 \mathrm{wt} . \%$ of the extracts is represented by saturates, and Sample 535-41-6, $120 \mathrm{~cm}$ (TOC $=0.9 \%$ ), where the saturates reach $13.9 \mathrm{wt} . \%$ of the extract. In these samples of Cenomanian age (Unit II), and more particularly in 535-35-4, $140 \mathrm{~cm}$ (Fig. 13A), the light alkanes $\mathrm{C}_{15}-\mathrm{C}_{17}$ are well represented, as are the alkanes between $C_{23}$ and $C_{31}$ with odd-numbered over even-numbered predominance; in the isoprenoids, however, the pristane is more abundant than phytane. Light $n$-alkanes in $\mathrm{C}_{15}-\mathrm{C}_{17}$ omnipresent in algae and bacteria indicate an aquatic origin for this organic matter, whereas the $\mathrm{C}_{23}-\mathrm{C}_{31} n$-alkanes, attributed to continental organic matter, is a common pattern of the DSDP Cretaceous sediments (Roucaché et al., 1979). The results of the kerogen elemental analysis located this sample, 535-35$4,140 \mathrm{~cm}$, beneath the beginning of evolution Path II $(\mathrm{H} / \mathrm{C}=1.22, \mathrm{O} / \mathrm{C}=0.15)$ (Fig. 12).

Furthermore, in Sample 535-64-4, 109-110 cm in which tar fills fracture perpendicular to the stratification, an extraction of the tar by chloroform was undertaken (Fig. 13B). The composition of the extract shows a high content of heteroatomic compounds (83.7 wt.\%), a relatively high aromatics content (14.4 wt. \%), and very little saturates (only $1.9 \mathrm{wt} . \%$ ). The gas chromatogram of the saturated + unsaturated fractions (Fig. 13B) shows a large predominance of $\mathrm{C}_{14}$ to $\mathrm{C}_{17}$ hydrocarbons, very 


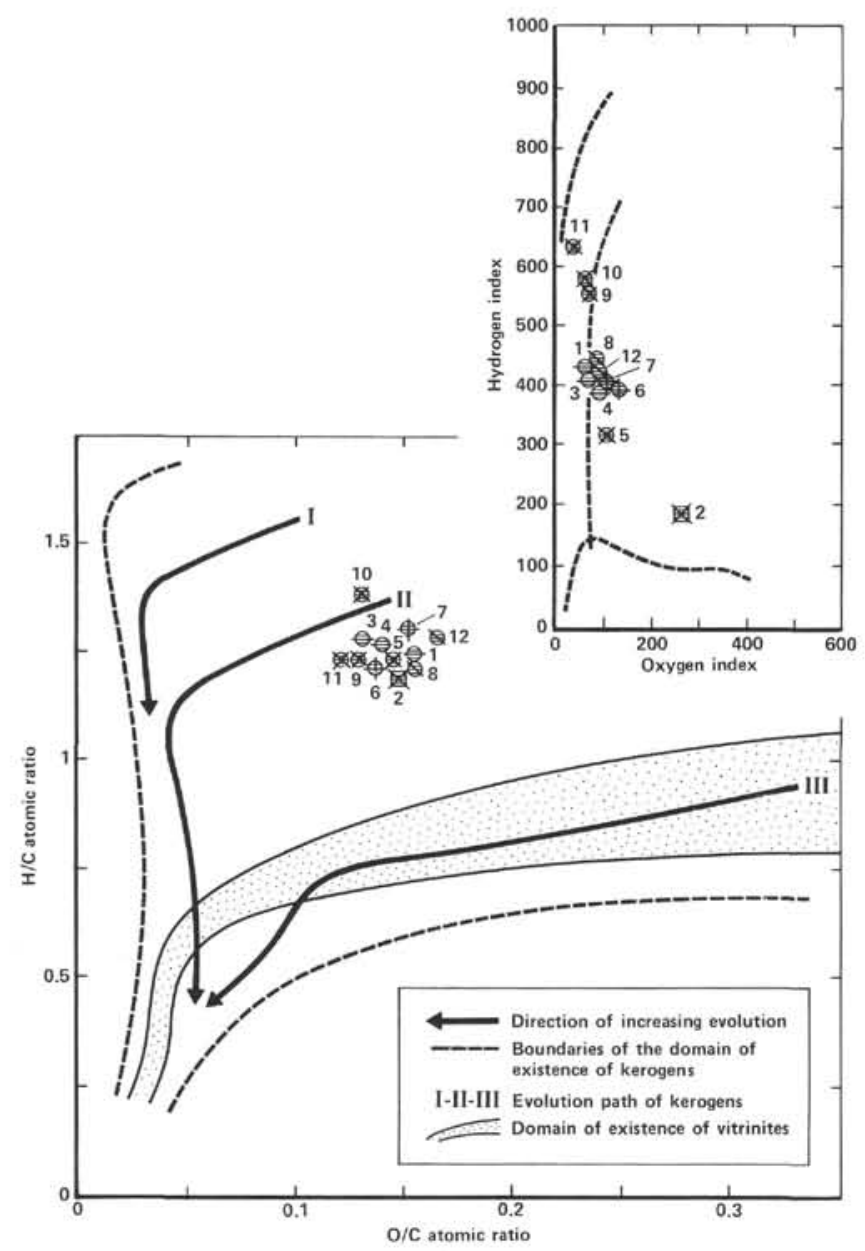

Figure 12. Kerogen: $\mathrm{H} / \mathrm{C}$ and $\mathrm{O} / \mathrm{C}$ diagram. Numbers represent samples as follows: $1: 535-35-4,140 \mathrm{~cm} ; 2: 535-41-6,120 \mathrm{~cm} ; 3: 535$ $52-3,120 \mathrm{~cm} ; 4: 535-54-4,120 \mathrm{~cm} ; 5: 535-60-5,120 \mathrm{~cm} ; 6: 535-64-3$, $142 \mathrm{~cm} ; 7: 535-64-3,145 \mathrm{~cm} ; 8: 535-64-4,16 \mathrm{~cm} ; 9: 535-64-4$, $101 \mathrm{~cm} ; 10: 535-64-4,118 \mathrm{~cm}$; 11: 535-64-4, $121 \mathrm{~cm}$; 12: 535-64-5, $23 \mathrm{~cm}$.

few alkanes beyond $\mathrm{C}_{18}$, and a high content of phytane. Such a composition could result either from an immature product issued from the surrounding source rock or from a biodegraded hydrocarbon accumulation issued from deeper deposits.

\section{CONCLUSIONS}

1) Organic matter of marine origin (Type II) characterizes the whole cored Cretaceous section $550 \mathrm{~m}$ thick, from Late Berriasian to Aptian and Cenomanian age.

2) The same range of maturation (just below the oil window) was found throughout the $550 \mathrm{~m}$ of Cretaceous sediment.

3) Two types of sedimentary facies control the distribution of the organic matter (OM): massive and lightcolored limestones or marly limestones in which the TOC content is low and the marine OM more or less oxidized, and the laminated and dark facies with a high TOC content and a well-preserved marine OM. Fluctuations from oxidizing to reducing environments of deposition probably account for the variations in properties of the OM without participation of Type III OM derived from continental sources.

4) Comparison with another Cretaceous carbonate section drilled off the continental margin of the Spanish Sahara (Site 369) suggests sedimentation above the CCD mainly characterized by an organic matter of marine origin.

5) Average petroleum potential values depend directly on the frequency and thickness of dark laminated layers provided with TOC content $\geq 0.5 \%$ (i.e., petroleum potential $\geq 2 \mathrm{~kg} \mathrm{HC} / \mathrm{T}$ rock).

6) From paleoenvironmental data, the sedimentologic history of Site 535 is rather different from those of aby'ssal sites in the northern central Atlantic. The hiatus equivalent to the E1 Event doesn't correspond to a variation of lithology between calcareous sedimentation with Type II OM (Blake-Bahama Formation) and a clayey one with Type III OM (Hatteras Formation), as at Sites 391 and 534. At Site 535, all the Cretaceous sediments remained calcareous with typical Type II OM in all the darker lithofacies and oxidized Type II OM in the others.

7) The sequential study excludes allochthonous sedimentation of slumping type because of the continuous variation in the properties of the OM from the lighter to the darker sediments. These alternations, very common in the Cretaceous sedimentation, would reflect the rhythmical anoxia of the environment and could be due to a

Table 2. Kerogen data from element analysis.

\begin{tabular}{|c|c|c|c|c|c|c|c|c|c|c|c|c|}
\hline \multirow[b]{2}{*}{ Unit } & \multirow{2}{*}{$\begin{array}{l}\text { Litho- } \\
\text { facies }\end{array}$} & \multirow{2}{*}{$\begin{array}{l}\text { Core-Section } \\
\text { (level in cm) }\end{array}$} & \multirow{2}{*}{$\begin{array}{c}\text { Depth } \\
\text { (m) }\end{array}$} & \multicolumn{6}{|c|}{ Weight percentage on ash-free basis } & \multirow{2}{*}{$\begin{array}{l}\text { Ash free } \\
\text { of pyrite } \\
\text { (wt.\%) }\end{array}$} & \multirow[b]{2}{*}{$\mathrm{H} / \mathrm{C}$} & \multirow[b]{2}{*}{$\mathrm{O} / \mathrm{C}$} \\
\hline & & & & C & $\mathrm{H}$ & $\mathrm{N}$ & 0 & $\mathbf{s}$ & $\mathrm{Fe}$ & & & \\
\hline \multirow[t]{2}{*}{ II } & 5 & & & & 3.73 & & 7.29 & & & 3.60 & 22 & \\
\hline & $x$ & & & 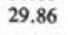 & & 1.9 & & ( & & 7.66 & 17 & 0.1 \\
\hline III & 을 & $52-3,120$ & 477.20 & 42.99 & 7.23 & 2.51 & 11.78 & 9.84 & 14.96 & 5.31 & 1.26 & 0.13 \\
\hline \multirow[t]{8}{*}{ IV } & - & $54-4,120$ & 492.70 & 43.48 & 4.52 & 2.45 & 8.08 & 22.20 & 14.12 & 6.04 & 1.25 & 0.14 \\
\hline & & & & & & & & & & & & \\
\hline & & & & & & & & 24 & & & & \\
\hline & & & & & & & & & & 7.6 & & .0. \\
\hline & 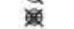 & & & & 5.07 & 1.31 & & & & 4.61 & & \\
\hline & 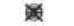 & & & & & & & & & & & \\
\hline & & & & & 6.39 & 2.03 & 10. & & & & & 0. \\
\hline & & $64-5,23$ & 585.23 & 44.09 & 4.60 & 1.44 & 9.70 & 22.95 & 13.25 & 3.97 & 1.25 & 0.16 \\
\hline
\end{tabular}

Note: See Table 1 for key to lithofacies symbols. 

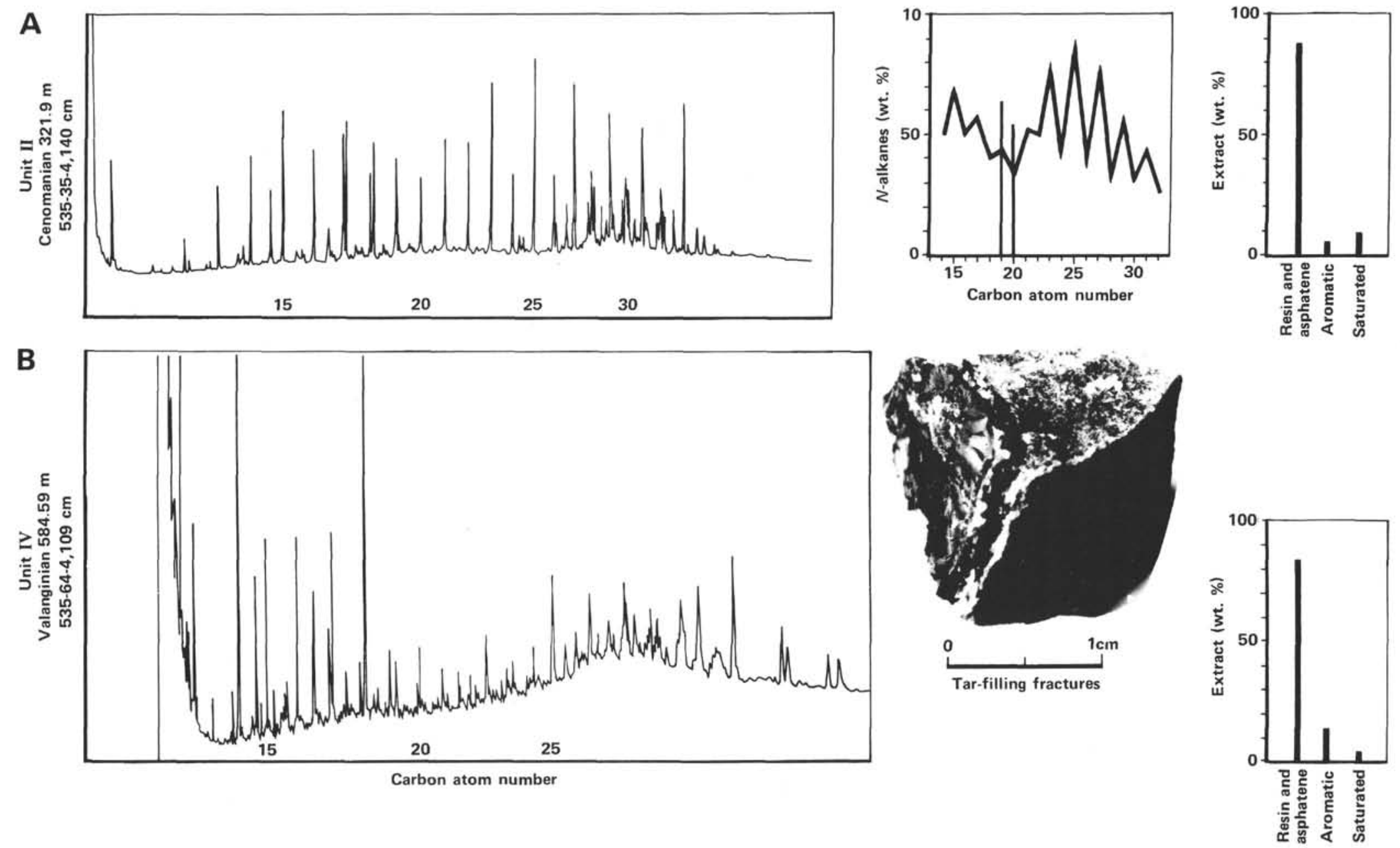

Figure 13. Chromatogram of the saturated + unsaturated fractions in the Cenomanian of Site 535 (A), and characterization of the tar-filling fractures in the Valanginian (B). 
Table 3. Composition of the extracts at Site 535.

\begin{tabular}{|c|c|c|c|c|c|c|c|c|c|c|c|c|c|c|}
\hline \multirow[b]{2}{*}{$\begin{array}{l}\text { Core-Section } \\
\text { (level in } \mathrm{cm})\end{array}$} & \multirow[b]{2}{*}{$\begin{array}{l}\text { Depth } \\
\text { (m) }\end{array}$} & \multirow[b]{2}{*}{ Unit } & \multirow[b]{2}{*}{ Age } & \multirow{2}{*}{$\begin{array}{c}\text { Weight } \\
\text { of rock } \\
\text { analyzed } \\
\text { (g) }\end{array}$} & \multirow[b]{2}{*}{$\begin{array}{c}\mathrm{CaCO}_{3} \\
(\%)\end{array}$} & \multirow[b]{2}{*}{$\begin{array}{l}\text { TOC } \\
(\%)\end{array}$} & \multirow[b]{2}{*}{$\mathrm{HI}$} & \multirow[b]{2}{*}{ OI } & \multirow[b]{2}{*}{$\begin{array}{l}T_{\max } \\
\left({ }^{\circ} \mathrm{C}\right)\end{array}$} & \multirow{2}{*}{$\begin{array}{c}\text { Extract/ } \\
\text { rock } \\
(\%)\end{array}$} & \multirow{2}{*}{$\begin{array}{c}\text { Extract/ } \\
\text { TOC } \\
(\%)\end{array}$} & \multirow{2}{*}{$\begin{array}{c}\text { Hetero- } \\
\text { atomic } \\
\text { compounds } \\
(\%)\end{array}$} & \multicolumn{2}{|c|}{$\begin{array}{l}\text { Hydrocarbon } \\
\text { fraction }\end{array}$} \\
\hline & & & & & & & & & & & & & $\begin{array}{c}\text { Aromatic } \\
(\%)\end{array}$ & $\begin{array}{c}\text { Saturated } \\
(\%)\end{array}$ \\
\hline $20-6,120$ & 182.20 & II & Cenomanian & 8.4 & 86 & 0.42 & 207 & 202 & 413 & 0.015 & 3.57 & & & \\
\hline $27-2,120$ & 242.70 & & & 9.1 & 80 & 0.37 & 132 & 316 & 413 & 0.013 & 3.51 & & & \\
\hline $35-4,140^{\mathrm{a}}$ & 321.90 & & & 6.5 & 82 & 2.24 & 435 & 75 & 413 & 0.034 & 1.52 & 86.7 & 5.3 & 8.0 \\
\hline $41-6,120^{\mathrm{a}}$ & 381.70 & & & 6.3 & 61 & 0.90 & 180 & 270 & 419 & 0.019 & 2.11 & 78.4 & 7.7 & 13.9 \\
\hline $47-1,82$ & 428.82 & III & early Barremian to late Hauterivian & 12.6 & 99 & 0.55 & 240 & 104 & 426 & 0.010 & 1.82 & 89.4 & 6.1 & 4.5 \\
\hline $47-1,91$ & 428.91 & & & 16.2 & 99 & 0.63 & 286 & 94 & 423 & 0.016 & 2.53 & 86.3 & 4.3 & 9.4 \\
\hline $47-1,93$ & 428.93 & & & 23.2 & 52 & 3.22 & 260 & 64 & 425 & 0.058 & 1.80 & 94.9 & 3.5 & 1.6 \\
\hline $47-1,99$ & 428.99 & & & 14.9 & 99 & 0.82 & 423 & 107 & 422 & 0.020 & 2.43 & 98.8 & 0. & 1.2 \\
\hline $47-1,112$ & 429.12 & & & 15.5 & 98 & 0.62 & 216 & 98 & 418 & 0.015 & 2.41 & & & \\
\hline $48-1,68$ & 437.68 & & & 9.8 & 99 & 0.13 & 77 & 123 & & 0.006 & 4.61 & & & \\
\hline $48-1,71$ & 437.71 & & & 14.1 & 79 & 1.35 & 315 & 90 & 428 & 0.004 & 0.30 & & & \\
\hline $48-1,149$ & 438.49 & & & 31. & 82 & 1.54 & 352 & 77 & 425 & 0.026 & 1.69 & 95.9 & 1.9 & 2.2 \\
\hline $48-3,120$ & 441.20 & & & 6.1 & 95 & 0.48 & 325 & 87 & 421 & 0.015 & 3.12 & & & \\
\hline $52-3,120$ & 477.20 & IV & Hauterivian & 6.6 & 80 & 1.79 & 418 & 75 & 408 & 0.037 & 2.07 & 90.4 & 6.1 & 3.5 \\
\hline $54-4,120$ & 492.70 & & Valanginian & 5.5 & 77 & 1.27 & 391 & 94 & 414 & 0.030 & 2.36 & 88.2 & 2.8 & 9.0 \\
\hline $60-5,120$ & 550.20 & & & 7.7 & 76 & 0.87 & 320 & 118 & 417 & 0.020 & 2.29 & 87.1 & 6.0 & 6.9 \\
\hline $64-4,48$ & 583.98 & & & 24. & 90 & 0.89 & 430 & 71 & 418 & 0.037 & 4.16 & 100.0 & 0. & 0 \\
\hline $64-4,90$ & 584.40 & & & 14.9 & 69 & 2.48 & 426 & 65 & 414 & 0.11 & 4.43 & 95.9 & 2.2 & 1.9 \\
\hline $66-5,129$ & 604.29 & & & 5.6 & 84 & 0.50 & 276 & 144 & 419 & 0.016 & 3.20 & & & \\
\hline $69-4,120$ & 625.20 & v & late Berriasian & 6.2 & 89 & 0.45 & 304 & 133 & 423 & 0.017 & 3.77 & & & \\
\hline
\end{tabular}

Note: $\mathrm{TOC}=$ total organic carbon; $\mathrm{HI}=$ hydrogen index $; \mathrm{OI}=$ oxygen index; $\mathrm{T}_{\max }=$ maximum temperature.

a Study of the saturated + unsaturated fraction by gas chromatography analysis on quartz col. capil. CP SIL 5 ( 0 int: $0.5 \mathrm{~mm}, \mathrm{~L}=25 \mathrm{~m}$ ), injected $0.2 \mu \mathrm{l}$ splitless (model Varian 3700 ).

sharply increased supply of nutrients. During the Early Cretaceous and mid-Cretaceous, the first stages of the continental drift, the physiography was certainly most important in controlling the anoxic environment. But why was the rhythmic phenomena spread all over the sealed basins of the central North Atlantic? The hypothesis of global climate fluctuation could be an explanation for the variations of the environment (Darmedru et al., 1982; Einsele, 1982).

\section{ACKNOWLEDGMENTS}

The authors are indebted to R. Cunningham and D. W. Waples for comment and review of the present paper and to P. C. de Graciansky who sampled and described Sections 3-5 in Core 535-64. Geology Paper Number 25712; Project B70 80006.

\section{REFERENCES}

Darmedru, C., Cotillon, P., and Rio, M., 1982. Rythmes climatiques et biologiques en milieu marin pélagique. Leurs relations dans les dépôts crétacés alternants du bassin vocontien (S.E. France). Bull. Soc. Geol. Fr., 7 Ser., 24(3):627-640.

de Graciansky, P. C., Brosse, E., Deroo, G., Herbin, J. P., Montadert, L., Müller, C., Sigal, J., and Schaaf, A., 1982. Les formations d'âge Crétacé de l'Atlantique Nord et leur matière organique: paléogéographie et milieux de dépôt. Rev. Inst. Fr. Pet., 37(3): 275-336.

Durand, B., and Oudin, J. L., 1979. Exemple de migration des hydrocarbures dans une série deltaïque: le delta de la Mahakam, Kalimantan, Indonésie. Proc. Tenth World Pet. Cong., Exploration, Supply, Demand, 2:3-11.

Einsele, G., 1982. Limestone-marl cycles (périodites): diagnosis, significance, causes-a review. In Einsele, G., and Seilacher, A. (Eds.), Cyclic and Event Stratification, pp. 3-11.

Espitalié, J., in press. Geochemical logging. In Voorhees, K. J. (Ed.), Proc. Fifth Int. Symp. Anal. Pyrolysis.

Espitalié, J., and Deroo, G., in press. The development of Rock-Eval analysis. In Ikan, R., and Aizenshtat, Z. (Eds.), Organic Thermogeochemistry.

Espitalié, J., Laporte, J. L., Madec, M., Marquis, F., Leplat, P., Paulet, J., and Boutefeu, A., 1977. Méthode rapide de caractérisation des roches mères, de leur potential pétrolier et de leur degré d'évolution. Rev. Inst. Fr. Pet., 32(1):3-40.
Espitalié J., Madec, M., and Tissot, B., 1980. Role of mineral matrix in kerogen pyrolysis: influence on petroleum generation and migration. Bull. Am. Assoc. Pet. Geol., 64(1):59-66.

Herbin, J. P., and Deroo, G., 1979. Etude sédimentologique de la matière organique dans les argiles noires crétacées de l'Atlantique Sud. Doc. Lab. Geol. Fac. Sci. Lyon, 75:71-87.

Roucache, J., Deroo, G., and Boulet, R., 1979. Caractérisation par différentes méthodes physico-chimiques de types de matière organique dans des sédiments du Crétacé d'Atlantique en mer profonde. Rev. Inst. Fr. Pet., 34(2):191-220.

Date of Initial Receipt: December 16, 1982

Date of Acceptance: June 15, 1983

APPENDIX

Carbonate, Organic Carbon, and Pyrolysis Data for Hole 535

\begin{tabular}{|c|c|c|c|c|c|c|c|c|c|}
\hline Unit & $\begin{array}{l}\text { Core-Section } \\
\text { (level in } \mathrm{cm})\end{array}$ & $\begin{array}{l}\text { Depth } \\
\text { (m) }\end{array}$ & $\begin{array}{c}\mathrm{CaCO}_{3} \\
(\%)\end{array}$ & $\begin{array}{l}\text { TOC } \\
(\%)\end{array}$ & $\begin{array}{l}\mathrm{T}_{\max } \\
\left({ }^{\circ} \mathrm{C}\right)\end{array}$ & HI & $\mathrm{HI}^{\prime}$ & OI & $\begin{array}{c}\mathrm{S}_{1}+\mathrm{S}_{2} \\
\text { (kg HC/t } \\
\text { rock) }\end{array}$ \\
\hline \multicolumn{10}{|c|}{ Limestone } \\
\hline \multicolumn{10}{|c|}{ White limestone } \\
\hline II & $35-4,97$ & 321.47 & 99 & 0.2 & & 165 & & 269 & 0.37 \\
\hline \multirow[t]{9}{*}{ III } & $46-2,67$ & 421.17 & 99 & 0.2 & & 186 & 318 & 173 & 0.46 \\
\hline & $47-1,82$ & 428.82 & 99 & 0.5 & 426 & 240 & & 104 & 1.34 \\
\hline & $47-1,99$ & 428.99 & 99 & 0.8 & 422 & 423 & & 107 & 3.68 \\
\hline & $47-1,122$ & 429.12 & 98 & 0.6 & 418 & 216 & & 98 & 1.43 \\
\hline & $48-1,68$ & 437.68 & 99 & 0.1 & & 77 & & 123 & 0.12 \\
\hline & $48-1,120$ & 438.20 & 97 & 0.3 & 423 & 145 & 172 & 138 & 0.42 \\
\hline & $48-1,148$ & 438.48 & 96 & 0.3 & 422 & 100 & & 82 & 0.28 \\
\hline & $49-3,137$ & 450.37 & 97 & 0.2 & & 229 & 417 & 129 & 0.61 \\
\hline & $51-1,199$ & 465.09 & 96 & 0.4 & 426 & 197 & 385 & 120 & 0.77 \\
\hline IV & $63-4,138$ & 575.88 & 99 & 0.2 & & 215 & & 180 & 0.46 \\
\hline \multirow[t]{2}{*}{ v } & $71-1,72$ & 638.20 & 96 & 0.1 & & 300 & & 325 & 0.29 \\
\hline & $72-3,124$ & 650.74 & 96 & 0.2 & & 113 & & 125 & 0.18 \\
\hline \multicolumn{10}{|c|}{ Pale yellow gray limestone } \\
\hline III & $47-1,91$ & 428.91 & 99 & 0.6 & 423 & 286 & & 94 & 1.83 \\
\hline \multicolumn{10}{|c|}{ Marly limestone } \\
\hline \multicolumn{10}{|c|}{ White marly limestone } \\
\hline II & $31-5,120$ & 285.20 & 94 & 0.3 & 428 & 123 & & 196 & 0.32 \\
\hline \multirow[t]{6}{*}{ III } & $48-1,85$ & 437.85 & 93 & 0.4 & 431 & 107 & 156 & 158 & 0.52 \\
\hline & $48-1,91$ & 437.91 & 95 & 0.4 & & 203 & & 150 & 0.73 \\
\hline & $48-1,98$ & 437.98 & 95 & 0.3 & 445 & 186 & 241 & 155 & 0.54 \\
\hline & $48-1,100$ & 438.00 & 89 & 0.6 & 422 & 208 & 290 & 126 & 1.29 \\
\hline & $48-1,108$ & 438.08 & 95 & 0.4 & 425 & 218 & & 105 & 0.83 \\
\hline & $51-1,32$ & 464.32 & 95 & 0.2 & & 120 & & 145 & 0.24 \\
\hline
\end{tabular}


Appendix A. (Continued).

\begin{tabular}{|c|c|c|c|c|c|c|c|c|c|}
\hline Unit & $\begin{array}{l}\text { Core-Section } \\
\text { (level in } \mathrm{cm} \text { ) }\end{array}$ & $\begin{array}{l}\text { Depth } \\
\text { (m) }\end{array}$ & $\underset{(\%)}{\mathrm{CaCO}_{3}}$ & $\begin{array}{l}\text { TOC } \\
(\%)\end{array}$ & $\mathrm{T}_{\max }$ & $\mathrm{HI}$ & $\mathrm{HI}^{\prime}$ & OI & $\begin{array}{c}\mathrm{S}_{1}+\mathrm{S}_{2} \\
\text { (kg HC/t } \\
\text { rock) }\end{array}$ \\
\hline \multicolumn{10}{|c|}{ Marly limestone (Cont.) } \\
\hline \multicolumn{10}{|c|}{ White marly limestone (Cont.) } \\
\hline \multirow[t]{25}{*}{ IV } & $55-6,132$ & 513.32 & 88 & 0.3 & 423 & 275 & 321 & 175 & 0.88 \\
\hline & $58-5,37$ & 531.37 & 92 & 0.4 & 423 & 367 & 535 & 86 & 1.86 \\
\hline & $60-6,25$ & 550.75 & 93 & 0.1 & & 100 & & 315 & 0.21 \\
\hline & $62-4,141$ & 566.91 & 95 & 0.1 & & 73 & & 187 & 0.24 \\
\hline & $64-3,11$ & 582.11 & 88 & 0.3 & 420 & 161 & 286 & 157 & 0.50 \\
\hline & $64-3,18$ & 582.18 & 90 & 0.3 & 423 & 150 & 231 & 162 & 0.43 \\
\hline & $64-3,29$ & 582.29 & 88 & 0.2 & 421 & 140 & 200 & 180 & 0.39 \\
\hline & $64-3,39$ & 582.39 & 89 & 0.2 & & 79 & & 184 & 0.17 \\
\hline & $64-3,49$ & 582.49 & 89 & 0.2 & 422 & 110 & & 170 & 0.24 \\
\hline & $64-3,59$ & 582.59 & 89 & 0.2 & & 84 & & 158 & 0.18 \\
\hline & $64-3,70$ & 582.70 & 89 & 0.2 & & 33 & & 228 & 0.09 \\
\hline & $64-3,80$ & 582.80 & 89 & 0.2 & & 89 & & 167 & 0.20 \\
\hline & $64-3,89$ & 582.89 & 90 & 0.2 & 422 & 65 & & 170 & 0.16 \\
\hline & $64-3,99$ & 582.99 & 89 & 0.0 & & & & & 0.09 \\
\hline & $64-3,109$ & 583.09 & 89 & 0.2 & & 47 & & 200 & 0.11 \\
\hline & $64-3,120$ & 583.20 & 88 & 0.0 & & & & & 0.20 \\
\hline & $64-3,129$ & 583.29 & 88 & 0.3 & 425 & 158 & 231 & 185 & 0.43 \\
\hline & $64-3,135$ & 583.35 & 84 & 0.4 & 423 & 213 & 342 & 153 & 0.85 \\
\hline & $64-5,34$ & 585.34 & 94 & 0.2 & & 112 & & 218 & 0.21 \\
\hline & $64-5,41$ & 585.41 & 93 & 0.0 & & & & & 0.17 \\
\hline & 645,47 & 585.47 & 92 & 0.0 & & & & & 0.19 \\
\hline & $64-5,56$ & 585.56 & 92 & 0.2 & & 74 & & 168 & 0.15 \\
\hline & $64-5,60$ & 585.60 & 91 & 0.2 & & 120 & & 230 & 0.26 \\
\hline & $64-5,76$ & 585.76 & 87 & 0.2 & & 150 & 250 & 215 & 0.33 \\
\hline & $66-4,109$ & 602.59 & 92 & 0.2 & & 210 & 286 & 224 & 0.58 \\
\hline \multirow[t]{6}{*}{ v } & $68-5,80$ & 617.30 & 93 & 0.2 & & 75 & & 160 & 0.20 \\
\hline & $69-1,120$ & 620.70 & 90 & 0.2 & & 43 & & 239 & 0.18 \\
\hline & $72-4,119$ & 652.19 & 94 & 0.1 & & 18 & & 336 & 0.16 \\
\hline & $73-1,101$ & 656.51 & 92 & 0.3 & 434 & 160 & 286 & 146 & 0.62 \\
\hline & $75-3,64$ & 677.14 & 76 & 0.3 & 427 & 137 & 185 & 304 & 0.44 \\
\hline & $75-3,79$ & 677.29 & 92 & 0.1 & & 27 & & 291 & 0.06 \\
\hline \multicolumn{10}{|c|}{ Pale yellow gray marly limestone } \\
\hline \multirow[t]{3}{*}{ II } & $39-4,97$ & 359.47 & 93 & 0.4 & 426 & 186 & 238 & 143 & 0.88 \\
\hline & $39-4,103$ & 359.53 & 92 & 0.2 & & 242 & 333 & 267 & 0.63 \\
\hline & $41-6,120$ & 381.70 & 91 & 0.6 & 424 & 218 & 375 & 173 & 1.26 \\
\hline III & $48-3,120$ & 441.20 & 95 & 0.5 & 421 & 325 & 333 & 87 & 1.59 \\
\hline IV & $57-5,120$ & 522.70 & 89 & 0.3 & 417 & 224 & & 169 & 0.70 \\
\hline \multicolumn{10}{|c|}{ Light gray marly limestone } \\
\hline \multirow[t]{5}{*}{ II } & $18-3,120$ & 158.70 & 90 & 0.4 & 413 & 157 & & 167 & 0.69 \\
\hline & $20-6,120$ & 182.20 & 86 & 0.4 & 413 & 207 & & 202 & 0.91 \\
\hline & $23-5,120$ & 209.20 & 88 & 0.5 & 416 & 180 & & 191 & 0.86 \\
\hline & $27-2,120$ & 242.70 & 80 & 0.4 & 413 & 132 & & 316 & 0.49 \\
\hline & $38-3,120$ & 348.70 & 87 & 0.3 & 414 & 42 & & 335 & 0.13 \\
\hline \multirow{9}{*}{ IV } & $64-4,128$ & 548.78 & 91 & 0.3 & 425 & 226 & & 194 & 0.75 \\
\hline & $64-4,131$ & 584.81 & 92 & 0.3 & 422 & 145 & 172 & 131 & 0.48 \\
\hline & $64-4,136$ & 584.86 & 91 & 0.3 & 428 & 303 & & 200 & 1.10 \\
\hline & $64-4,141$ & 584.91 & 89 & 0.8 & 425 & 591 & 763 & 69 & 6.08 \\
\hline & $64-4,143$ & 584.93 & 92 & 0.2 & & 185 & 300 & 170 & 0.45 \\
\hline & $64-4,149$ & 584.99 & 91 & 0.3 & 425 & 263 & 344 & 163 & 0.93 \\
\hline & $64-5,0$ & 585.00 & 91 & 0.2 & 420 & 167 & 208 & 246 & 0.43 \\
\hline & $64-5,9$ & 585.09 & 91 & 0.3 & 429 & 158 & 173 & 158 & 0.42 \\
\hline & $64-5,17$ & 585.17 & 90 & 0.5 & 425 & 383 & 489 & 111 & 2.10 \\
\hline \multicolumn{10}{|c|}{ Dark gray marly limestone } \\
\hline II & $35-4,82$ & 321.32 & 81 & 1.5 & 427 & 413 & 523 & 103 & 6.80 \\
\hline \multicolumn{10}{|c|}{ Laminated marty limestone } \\
\hline Laminat & d white marly & mestone & & & & & & & \\
\hline III & $48-1,100$ & 438.00 & 89 & 0.6 & 422 & 208 & 290 & 126 & 1.29 \\
\hline & $49-3,111$ & 450.11 & 93 & 0.9 & 415 & 387 & 652 & 85 & 3.76 \\
\hline IV & $54-2,68$ & 489.18 & 84 & 0.8 & 417 & 390 & 474 & 93 & 3.20 \\
\hline & $66-5,129$ & 604.29 & 84 & 0.5 & 419 & 276 & & 144 & 1.44 \\
\hline v & $68-5,97$ & 697.47 & 82 & 0.6 & 427 & 326 & 385 & 140 & 2.25 \\
\hline & $69-4,120$ & 625.20 & 89 & 0.4 & 423 & 304 & & 133 & 1.43 \\
\hline & $71-1,110$ & 638.60 & 91 & 0.6 & 429 & 339 & 393 & 132 & 1.99 \\
\hline
\end{tabular}

Appendix A. (Continued).

\begin{tabular}{|c|c|c|c|c|c|c|c|c|c|}
\hline Unit & $\begin{array}{l}\text { Core-Section } \\
\text { (level in } \mathrm{cm} \text { ) }\end{array}$ & $\begin{array}{c}\text { Depth } \\
(\mathrm{m})\end{array}$ & $\underset{(\%)}{\mathrm{CaCO}_{3}}$ & $\begin{array}{l}\text { Toc } \\
(\%)\end{array}$ & $\begin{array}{l}\mathrm{T}_{\max } \\
\left({ }^{\circ} \mathrm{C}\right)\end{array}$ & $\mathrm{HI}$ & $\mathrm{HI}^{\prime}$ & OI & $\begin{array}{c}\mathrm{S}_{1}+\mathrm{S}_{2} \\
(\mathrm{~kg} \mathrm{HC} / \mathrm{H} \\
\text { rock) }\end{array}$ \\
\hline \multicolumn{10}{|c|}{ Laminated marry limestone (Cont.) } \\
\hline \multicolumn{10}{|c|}{ Laminated pale yellow gray marly limestone } \\
\hline IV & $\begin{array}{l}64-3,139 \\
64-3,142 \\
64-3,145\end{array}$ & $\begin{array}{l}583.39 \\
583.42 \\
583.45\end{array}$ & $\begin{array}{l}84 \\
77 \\
75\end{array}$ & $\begin{array}{l}0.6 \\
0.9 \\
1.0\end{array}$ & $\begin{array}{l}421 \\
421 \\
422\end{array}$ & $\begin{array}{l}313 \\
391 \\
400\end{array}$ & $\begin{array}{l}550 \\
681 \\
653\end{array}$ & $\begin{array}{l}142 \\
112 \\
101\end{array}$ & $\begin{array}{l}1.98 \\
3.76 \\
4.26\end{array}$ \\
\hline \multicolumn{10}{|c|}{ Laminated gray marly limestone } \\
\hline $\begin{array}{l}\text { III } \\
\text { IV }\end{array}$ & $\begin{array}{l}51-4,94 \\
54-2,50 \\
55-6,115 \\
58-5,59 \\
60-5,97 \\
64-4,1 \\
64-4,7 \\
64-4,8 \\
64-4,16 \\
64-4,20 \\
64-4,21 \\
64-4,27 \\
64-4,31 \\
64-4,32 \\
64-4,36 \\
64-4,43 \\
64-4,48 \\
64-4,49 \\
64-4,122 \\
64-5,23\end{array}$ & $\begin{array}{l}469.44 \\
489.00 \\
505.15 \\
51.59 \\
549.97 \\
583.51 \\
583.57 \\
583.58 \\
58.56 \\
583.70 \\
583.71 \\
583.77 \\
583.81 \\
583.82 \\
583.86 \\
583.93 \\
583.98 \\
583.99 \\
584.72 \\
585.23\end{array}$ & $\begin{array}{l}75 \\
67 \\
75 \\
72 \\
74 \\
71 \\
71 \\
74 \\
72 \\
78 \\
81 \\
83 \\
84 \\
86 \\
82 \\
87 \\
90 \\
86 \\
85 \\
74\end{array}$ & $\begin{array}{l}1.2 \\
1.6 \\
2.2 \\
1.1 \\
1.4 \\
1.2 \\
1.7 \\
1.2 \\
1.4 \\
0.9 \\
0.9 \\
0.8 \\
0.8 \\
0.8 \\
0.8 \\
0.6 \\
0.9 \\
0.8 \\
0.7 \\
0.8\end{array}$ & $\begin{array}{l}422 \\
417 \\
410 \\
420 \\
419 \\
421 \\
418 \\
420 \\
420 \\
421 \\
420 \\
419 \\
420 \\
419 \\
419 \\
420 \\
418 \\
419 \\
421 \\
419\end{array}$ & $\begin{array}{l}340 \\
393 \\
414 \\
371 \\
388 \\
435 \\
455 \\
415 \\
410 \\
374 \\
383 \\
346 \\
367 \\
375 \\
370 \\
343 \\
430 \\
354 \\
320 \\
406\end{array}$ & $\begin{array}{l}557 \\
606 \\
519 \\
546 \\
533 \\
656 \\
619 \\
530 \\
660 \\
579 \\
500 \\
587 \\
487 \\
654 \\
476 \\
585 \\
494 \\
536 \\
548\end{array}$ & $\begin{array}{r}104 \\
88 \\
77 \\
101 \\
85 \\
97 \\
80 \\
94 \\
86 \\
106 \\
95 \\
104 \\
111 \\
99 \\
100 \\
111 \\
71 \\
109 \\
138 \\
99\end{array}$ & $\begin{array}{l}4.30 \\
6.79 \\
9.39 \\
4.25 \\
5.66 \\
5.75 \\
8.14 \\
5.12 \\
6.23 \\
3.73 \\
3.76 \\
2.93 \\
2.94 \\
3.24 \\
3.30 \\
2.38 \\
4.03 \\
2.93 \\
2.35 \\
3.64\end{array}$ \\
\hline \multicolumn{10}{|c|}{ Laminated dark gray marly limestone } \\
\hline III & $\begin{array}{l}48-1,71 \\
48-1,74 \\
48-1,78 \\
48-1,149 \\
60-5,120 \\
64-4,90 \\
64-4,95 \\
64-4,101 \\
64-4,118 \\
64-4,121\end{array}$ & $\begin{array}{l}437.71 \\
437.74 \\
437.78 \\
438.49 \\
550.20 \\
584.40 \\
584.45 \\
584.51 \\
58.68 \\
584.71\end{array}$ & $\begin{array}{l}76 \\
69 \\
77 \\
80 \\
71 \\
80\end{array}$ & $\begin{array}{l}1.3 \\
1.0 \\
0.7 \\
1.5 \\
0.9 \\
2.5 \\
1.8 \\
1.6 \\
3.6 \\
3.2\end{array}$ & $\begin{array}{l}428 \\
432 \\
431 \\
425 \\
417 \\
414 \\
4115 \\
420 \\
413 \\
419\end{array}$ & $\begin{array}{l}315 \\
297 \\
256 \\
352 \\
320 \\
426 \\
445 \\
568 \\
582 \\
642\end{array}$ & $\begin{array}{l}430 \\
459 \\
370 \\
455 \\
356 \\
524 \\
\\
642 \\
699 \\
692\end{array}$ & $\begin{array}{r}90 \\
108 \\
100 \\
77 \\
118 \\
65 \\
63 \\
54 \\
51 \\
46\end{array}$ & $\begin{array}{r}4.37 \\
3.13 \\
1.91 \\
5.55 \\
2.92 \\
11.17 \\
8.67 \\
10.91 \\
22.80 \\
23.46\end{array}$ \\
\hline \multicolumn{10}{|c|}{ Laminated dark olive gray marly limestone } \\
\hline $\begin{array}{c}\text { II } \\
\text { III } \\
\text { IV } \\
\text { V }\end{array}$ & & & $\begin{array}{l}82 \\
80 \\
77 \\
74 \\
\end{array}$ & 2.2 & $\begin{array}{l}413 \\
408 \\
414 \\
419\end{array}$ & $\begin{array}{l}435 \\
418 \\
391 \\
304 \\
\end{array}$ & $\begin{array}{l}480 \\
394 \\
460 \\
\end{array}$ & $\begin{array}{l}75 \\
75 \\
94 \\
78 \\
\end{array}$ & $\begin{array}{r}10.16 \\
7.80 \\
5.11 \\
7.49 \\
\end{array}$ \\
\hline \multicolumn{10}{|l|}{ Marls } \\
\hline \multicolumn{10}{|c|}{ Dark gray marls } \\
\hline $\begin{array}{l}\text { III } \\
\text { IV } \\
\text { v }\end{array}$ & $\begin{array}{l}46-2,26 \\
49-3,101 \\
62-2,42 \\
73-1,93\end{array}$ & $\begin{array}{l}420.76 \\
450.01 \\
562.92 \\
656.43\end{array}$ & $\begin{array}{l}62 \\
65 \\
61 \\
41\end{array}$ & $\begin{array}{l}2.3 \\
2.5 \\
1.4 \\
2.8\end{array}$ & $\begin{array}{l}427 \\
416 \\
425 \\
428\end{array}$ & $\begin{array}{l}380 \\
403 \\
383 \\
306\end{array}$ & $\begin{array}{l}590 \\
570 \\
621 \\
594\end{array}$ & $\begin{array}{l}81 \\
78 \\
97 \\
91\end{array}$ & $\begin{array}{r}9.26 \\
10.45 \\
5.83 \\
8.88\end{array}$ \\
\hline \multicolumn{10}{|c|}{ Very dark gray marls } \\
\hline $\begin{array}{l}\text { III } \\
\text { IV }\end{array}$ & $\begin{array}{l}47-1,93 \\
64-4,70\end{array}$ & $\begin{array}{l}428.93 \\
584.20\end{array}$ & $\begin{array}{l}52 \\
56\end{array}$ & $\begin{array}{l}3.2 \\
5.7\end{array}$ & $\begin{array}{l}425 \\
413\end{array}$ & $\begin{array}{l}260 \\
578\end{array}$ & $\begin{array}{l}391 \\
632\end{array}$ & $\begin{array}{l}64 \\
44\end{array}$ & $\begin{array}{r}8.69 \\
35.28\end{array}$ \\
\hline \multicolumn{10}{|c|}{ Laminated dark gray marls } \\
\hline II & $\begin{array}{l}41-6,120 \\
69-1,115\end{array}$ & 620.65 & $\begin{array}{l}61 \\
60\end{array}$ & $\begin{array}{l}0.9 \\
1.6\end{array}$ & $\begin{array}{l}419 \\
426\end{array}$ & $\begin{array}{l}180 \\
425\end{array}$ & 564 & $\begin{array}{l}270 \\
113\end{array}$ & $\begin{array}{l}1.72 \\
7.42\end{array}$ \\
\hline \multicolumn{10}{|c|}{ Laminated dark olive gray marls } \\
\hline$\underset{\mathrm{v}}{\mathrm{IV}}$ & $\begin{array}{l}66-4,76 \\
71-3,122\end{array}$ & $\begin{array}{l}602.26 \\
641.72\end{array}$ & $\begin{array}{l}61 \\
53\end{array}$ & $\begin{array}{l}2.4 \\
1.9\end{array}$ & $\begin{array}{l}417 \\
425\end{array}$ & $\begin{array}{l}512 \\
439\end{array}$ & $\begin{array}{l}686 \\
563\end{array}$ & $\begin{array}{l}70 \\
85\end{array}$ & $\begin{array}{r}13.28 \\
8.72\end{array}$ \\
\hline
\end{tabular}

Note: $\mathrm{TOC}=$ total organic carbon; $\mathrm{T}_{\max }=$ maximum temperature; $\mathrm{HI}=$ hydrogen index; $\mathrm{HI}^{\prime}=$ corrected hydrogen index; $\mathrm{OI}=$ oxygen index; $\mathrm{S}_{1}+\mathrm{S}_{2}=$ petroleum potential; $\mathrm{HC}$ 